\title{
Measurements of Radiofrequency Radiation with a Body-Borne Exposimeter in Swedish Schools with Wi-Fi
}

\section{Lena K. Hedendahl'*, Michael Carlberg ${ }^{2}$, Tarmo Koppel ${ }^{3}$ and Lennart Hardell ${ }^{2}$}

${ }^{1}$ Independent Environment and Health Research Luleå, Sweden, ${ }^{2}$ Department of Oncology, Faculty of Medicine and Health, University Hospital, Örebro, Sweden, ${ }^{3}$ Department of Work Environment and Safety, Tallinn University of Technology, Tallinn, Estonia

Introduction: Wireless access to the Internet is now commonly used in schools. Many schools give each student their own laptop and utilize the laptops and wireless fidelity (Wi-Fi) connection for educational purposes. Most children also bring their own mobile phones to school. Since children are obliged by law to attend school, a safe environment is important. Lately, it has been discussed if radiofrequency (RF) radiation can have long-term adverse effects on children's health.

OPEN ACCESS

Edited by:

Wilhelm Mosgoeller,

Medical University of Vienna,

Austria

Reviewed by:

David O. Carpenter,

University at Albany, SUNY,

United States

Hanns Moshammer,

Medical University of Vienna, Austria

${ }^{*}$ Correspondence:

Lena K. Hedendah

lenahedendahl@telia.com

Specialty section: This article was submitted to

Radiation and Health,

a section of the journal

Frontiers in Public Health

Received: 30 June 2017 Accepted: 29 September 2017

Published: 20 November 2017

Citation:

Hedendahl LK, Carlberg M, Koppel T and Hardell L (2017) Measurements

of Radiofrequency Radiation with a Body-Borne Exposimeter in

Swedish Schools with Wi-Fi.

Front. Public Health 5:279.

doi: 10.3389/fpubh.2017.00279
Method: This study conducted exposimetric measurements in schools to assess RF emissions in the classroom by measuring the teachers' RF exposure in order to approximate the children's exposure. Teachers in grades 7-12 carried a body-borne exposimeter, EME-Spy 200, in school during 1-4 days of work. The exposimeter can measure 20 different frequency bands from 87 to $5,850 \mathrm{MHz}$.

Results: Eighteen teachers from seven schools participated. The mean exposure to RF radiation ranged from 1.1 to $66.1 \mu \mathrm{W} / \mathrm{m}^{2}$. The highest mean level, $396.6 \mu \mathrm{W} / \mathrm{m}^{2}$, occurred during 5 min of a lesson when the teacher let the students stream and watch YouTube videos. Maximum peaks went up to $82,857 \mu \mathrm{W} / \mathrm{m}^{2}$ from mobile phone uplink.

Discussion: Our measurements are in line with recent exposure studies in schools in other countries. The exposure levels varied between the different Wi-Fi systems, and if the students were allowed to use their own smartphones on the school's Wi-Fi network or if they were connected to GSM/3G/4G base stations outside the school. An access point over the teacher's head gave higher exposure compared with a school with a wired Internet connection for the teacher in the classroom. All values were far below International Commission on Non-lonizing Radiation Protection's reference values, but most mean levels measured were above the precautionary target level of 3-6 $\mu \mathrm{W} / \mathrm{m}^{2}$ as proposed by the Bioinitiative Report. The length of time wireless devices are used is an essential determinant in overall exposure. Measures to minimize children's exposure to $\mathrm{RF}$ radiation in school would include preferring wired connections, allowing laptops, tablets and mobile phones only in flight mode and deactivating Wi-Fi access points, when not used for learning purposes.

Keywords: radiofrequency radiation, wireless fidelity, Wi-Fi, exposimetric measurements, schools, children, health 


\section{INTRODUCTION}

In recent years, the education in many schools has changed considerably, from classes where the teacher holds lectures in front of a class, where every student has his/her own school books to read and write in, to classes where all students use their own laptop and no printed text books. The teacher may act as a mentor in the individually based education where the students work at their own pace and capacity directly through different programs on their personal laptops. Access to the Internet is, in most schools, available through wireless connection, wireless fidelity (Wi-Fi). There is usually a network of access points for Wi-Fi in classrooms and corridors to make it possible to teach and keep in contact everywhere in the school building. Most students and teachers also bring their own mobile phones, usually a smartphone, with them to class and use them for social communication and entertainment throughout the day. Besides Wi-Fi, other mobile networking protocols are also actively used-subscription to $3 \mathrm{G}$ and $4 \mathrm{G}$ wireless connections find widespread use among school children.

Information and communication technology (ICT) is an important field in teaching in our schools, both for every student to learn how to get information in different subjects and as a tool to learn and practice knowledge. Most students and teachers appreciate the development of more technology in school education and are very positive to all advantages it brings.

However, the benefits of ICT in education seem to be largely unproven and there are also concerns that there may be side effects (1). Results from the OECD's PISA performance surveys from 2012 in reading and mathematics show decreasing results in countries that have invested the most in introducing computers in schools. Sweden is the country that deteriorated the most in the PISA performance surveys in mathematics and reading between 2003 and 2012. At the same time, Sweden was one of the countries that had invested the most in introducing computers in school (2). Results from the PISA performance surveys 2015 from Sweden in reading and mathematics show better results and are now just above the OECD average. However, Sweden is still well below its scores in 2003 (3).

Multitasking, to do several things at the same time, means that your attention has to shift focus between different activities. The brain can only concentrate on one matter at the time. Swift shifting of focus between different tasks may lead to impaired ability to store memories and knowledge (4-7). Even to have nearby classmates surfing on the Internet can impair learning (8). The time used to check their smartphone for new messages can give a positive feeling of being updated but takes time and concentration from school work (9).

Apart from during school time, most students use their smartphones, laptops, and tablets during evenings for several hours. In the yearly inquiry 2015/2016 in the schools in the county of Norrbotten in Sweden, $80 \%$ of the 16 -year-old students spent at least $3 \mathrm{~h}$ in front of a screen in their free time. Five hours or more were spent by $35 \%$ (10). If the students also use a laptop during most classes in school, it can add up to many hours of screen time every day. A study in the United States concluded that college students spent nearly $9 \mathrm{~h}$ a day on their cell phones (11).

Screen time can affect us in many different ways. Long hours of sitting in front of a screen can lead to aches in the neck, back, and shoulders. In the yearly inquiry in Norrbotten, almost one-fourth of the 16-year-old girls often had aches in their neck, back, or shoulder (10).

Screen time has been shown to have a higher correlation to overweight and obesity than lack of physical activity (12), since prolonged sedentary activities can be a metabolic risk factor (13) and less physical activity may reduce cardiorespiratory fitness (14). There are also concerns about the emotional development for especially young children with a high amount of screen time. Time is taken from play, physical activities, and being with friends, parents, and siblings, which are important parts when growing up. The development of mirror neurons in the brain, which give us the possibility to imitate the behavior of other people, can be affected (15). Empathetic concern among American college students has dropped sharply since 1979 and especially since the year of 2000 according to a meta-analysis on studies performed between 1979 and 2009 (16).

High ICT usage among young adults in Gothenburg led to an increased risk for depression, sleep problems, and stress (17). Among adolescents in Japan using a mobile phone after lights out at night gave sleep disturbances, increased tiredness during day time, and several had suicide thoughts and worse mental health $(18,19)$. In a review, bedtime access and use of portable screenbased media devices showed a statistically significant association with inadequate sleep quality, poor sleep quality, and excessive daytime sleepiness (20). Increased duration of mobile phone use has been linked to higher risks for depressed mood and mobile phone addiction $(11,21,22)$.

Adolescents at risk for mental health problems showed an association between both the amount of time spent using digital technologies and the numbers of text messages sent and increased same-day symptoms from attention deficit hyperactivity (ADHD) and conduct disorders (23). One study in Switzerland raised the question "whether problematic mobile phone use is the consequence of unfavorable conditions or whether and to what extent problematic mobile phone use reinforces behavioral problems as well as decreased mood and psychological well-being" (24).

In the WHO study, Health Behavior in School-aged Children (HBSC) conducted during 2013/2014 results from Sweden showed that girls' mental health has deteriorated compared with the same study made during 2009/2010. The study has since 1985/1986 taken place around the world every fourth year among 11-, 13-, and 15-year-old girls and boys in over 40 different countries. In Sweden, sleep problems in particular have increased among 13- and 15-year-old girls. Of the girls, $39 \%$ have sleep problems more than once a week. Also, boys at the same age have sleeping problems, though to a lesser extent (around 27\%). To feel depressed, nervous, or irritated has increased among Swedish, 13- and 15-year-old girls and were about twice as common compared with boys at the same age. The conclusion of the HBSC report brings up that "the fast technical development has changed children's and adolescents' everyday life in many ways, which may have influenced their mental well-being" (25). In the latest yearly inquiry in Norrbotten, Sweden, there is a statistically significant correlation between school districts with high amount of screen time and how many students in the community that feel depressed (10). 
Considering the long hours of screen time and deteriorating health with increasing problems with sleep, depression, and aches among students, there are concerns regarding whether radiofrequency (RF) radiation from wireless networks, laptops, and mobile phones is harmless below reference values of RF radiation and if there can be potential adverse health effects from this exposure in the long term.

The reference values for $\mathrm{RF}$ radiation $10 \mathrm{MHz}$ to $300 \mathrm{GHz}$ were recommended in 1998 by the International Commission on NonIonizing Radiation Protection (ICNIRP) to $2-10 \mathrm{~W} / \mathrm{m}^{2}$ depending on frequency (26). This reference value protects against injuries caused by a heating effect over $1^{\circ} \mathrm{C}$ after an exposure of $30 \mathrm{~min}$, and with a safety factor of 50 . Injuries caused by other biological mechanisms than heating or from chronic effects of RF radiation are not taken into account in the ICNIRP's reference values. Sweden and many other countries apply the reference value of $10 \mathrm{~W} / \mathrm{m}^{2}\left(10,000,000 \mu \mathrm{W} / \mathrm{m}^{2}\right)$ for frequencies $2-300 \mathrm{GHz}$. Some countries, like Russia, Poland, Italy, India, and China have chosen lower reference values down to $0.1 \mathrm{~W} / \mathrm{m}^{2}\left(100,000 \mu \mathrm{W} / \mathrm{m}^{2}\right)(27)$. In 2012, the Bioinitiative Working Group proposed a precautionary target level of $3-6 \mu \mathrm{W} / \mathrm{m}^{2}$, with a safety factor of 10 , since research studies on biological effects have shown biological effects of RF radiation down to $30-60 \mu \mathrm{W} / \mathrm{m}^{2}$ (28).

The Council of Europe recommended in a resolution from 2011 that schools and other buildings where children spend their time should give preference to wired Internet connections and implement information and awareness-raising campaigns on the risks of potentially harmful long-term biological effects on human health from wireless technology, especially targeting children, teenagers, and people of reproductive age (29). In France, mobile phones are not allowed up to sixth grade in school. Israel and Cyprus have recommendations to not have wireless networks in preschool and to turn off Wi-Fi when not used in primary schools. Many schools in Sweden have started to ban mobile phones during school time since they disturb the students' concentration on school work.

Exposure to RF radiation was classified as a possible human carcinogen, Group 2B, by the International Agency for Research on Cancer (IARC) at WHO in 2011. The decision was mainly based on case-control human studies on use of wireless phones by the Hardell group from Sweden and the IARC Interphone study, which showed increased risk for brain tumors, i.e., glioma and acoustic neuroma (30-33). Further research has confirmed the increased risk for brain tumors and mobile phone use (34-37). A report released in 2016 from the National Toxicology Program under the National Institutes of Health in the United States strengthened the association between RF radiation and cancer. An increased incidence of glioma in the brain and malignant schwannoma in the heart was found in life-long RF radiated rats (38), thereby supporting human epidemiological studies on brain tumor risk. Several laboratory studies have shown mechanistic effects in carcinogenesis such as oxidative stress, down regulation of mRNA and DNA damage with single strand breaks (39-43).

The risk for cancer may be accentuated for children partly because of their likely longer life-time use of wireless devices, but also since their smaller size and thinner skull bone give higher RF radiation to the brain (44). Children are also growing and have more immature cells which can be more sensible to RF radiation $(41,45)$.
Beside the cancer risk, studies with laboratory animals have shown that RF radiation may open the blood-brain barrier and may thereby increase the rate toxic molecules enter the brain tissue, hurt neurons in the hippocampus (the brain center for memory), impair spatial memory in exposed rats (46-49), and down or up regulate essential proteins in the brain engaged in the brain's metabolism, stress response, and neuro-protection (50). Long-term, low intensity of RF radiation exposure has also shown reduced levels of neurotransmitters and key-regulating enzymes in the rat brain (51). Increase in frequency seems to have more deleterious effect on several of the parameters (42).

Long-time exposure from a new GSM base station in Rimbach, Germany revealed adverse effects on neurotransmittors like Epinephrine, Norepinephrine, Dopamine, and Phenyletylamine which after 18 months had not normalized, especially not in children and chronically ill adults (52). Chronic dysregulation of psychobiological stress markers may contribute to health problems and chronic illnesses. More behavioral problems have been seen in children with higher exposure to RF radiation compared with children with lower exposure (53-56).

Several studies on humans indicate an influence on the electrical activity in the brain seen in EEGs after exposure to RF radiation during both sleep and in active memory tests $(57,58)$. Other studies on people exposed to RF radiation from mobile phones have shown disturbed glucose metabolism in the brain (59), effects on endocrine system (60), and in young adults with high-cumulative amounts of hours of mobile phone use, decreased $\beta$-trace protein, which is a key enzyme in the synthesis of a sleep-promoting neurohormone (61). DNA damage has also been found in hair root cells after $30 \mathrm{~min}$ of mobile phone talk (62) and buccal mucosal cells in high-mobile phone users with more than $10 \mathrm{~h}$ of mobile phone use per week for over 5 years (63).

Wireless fidelity exposure on testes and sperms has led to decreased sperm mobility, more head defects, and DNA damage $(39,64-66)$. Wi-Fi signals in studies on laboratory animals have had effects on heart rhythm and blood pressure after $1 \mathrm{~h}$ of exposure (67). Low-intensity long-term exposure to $\mathrm{Wi}$-Fi up to 12 months in animals induced oxidative stress in the lens (68), increase in pro-inflammatory cytokines, oxidative stress, and DNA damage with single strand breaks in the hippocampus in the brain (42), down regulation of microRNA expression in brain tissue (40), and cognitive impairment and DNA damage (69). In humans, Wi-Fi exposure during a language test showed gender-related effects on EEG in a large area of the brain (70), but no effect on EEG or on a psychomotor vigilance test during a 60-min Wi-Fi exposure (71).

It is important to collect information about the $\mathrm{RF}$ radiation exposure in schools to consider the best technological devices used in education regarding convenience and economy, but also to consider the potential long-term health effects as mentioned above.

The aim of this study was to assess RF emissions in the classroom by measuring the teachers' RF exposure and thereby to approximate the children's exposure but also to identify the main sources of exposure. The investigated schools were equipped with a wireless infrastructure. We wanted to evaluate the measured RF radiation levels in relation to ICNIRPs' and Sweden's reference 
values, but also in relation to countries with stricter safety limits and to the Bioinitiative Working Group's suggested level. Furthermore, we wanted to compare our measured results with exposimetric studies in schools in other countries. Finally, based on measurements results, we discuss strategies for RF radiation risk management in schools.

\section{MATERIALS AND METHODS}

This is a descriptive study with measurements of exposure to RF radiation in schools with $\mathrm{Wi}-\mathrm{Fi}$ and one laptop for each student. School principals were contacted by phone and if interested, information was sent by mail. The principal, or in some cases interested teachers, recruited the teachers willing to participate. All teachers were informed both by written information and personally at the start of measurements by one of the researchers. All teachers signed a statement of agreement to participate before starting the measurements in accordance with the declaration of Helsinki. The Ethical Committee approved the study (Uppsala University DNR 2015/485).

In total, 18 teachers were recruited from seven schools, both rural and urban. The schools were located in the city of Örebro in the middle of Sweden and in the county of Norrbotten in the northern part. The included schools had from 28 to 1,300 students (Table 1). The teachers carried the exposimeter (weight $440 \mathrm{~g}$ ) in a small and comfortable shoulder bag. The exposimeter was carried during the whole working day. If the teacher also carried a mobile phone on the body, the teacher was advised to place it on the opposite side from the exposimeter. Signals from the mobile phones did not affect the results as the exposimeter is capable of discriminating between upload and download bands. The teachers were carrying the exposimeter from 1 to 4 days.

The teachers handed over their work schedule and also filled in a questionnaire about (1) the school building, (2) classroom for each lesson, teachers' office or lunch room, (3) if there was any access point for Wi-Fi in the room, (4) the number of students in each class, (5) if they used their laptops, (6) if they were connected to the Internet and if so for how long time, and (7) if the

TABLE 1 | Participating teachers and schools.

\begin{tabular}{lccl}
\hline Teacher & Grades & Number of students & Urban, rural \\
\hline MH1 & $7-9$ & 85 & Urban \\
MH2 & $7-9$ & 85 & Urban \\
MH3 & $7-9$ & 85 & Urban \\
OH & $7-9$ & 111 & Rural \\
SH & $7-9$ & 28 & Rural \\
LG1 & $10-12$ & 170 & Rural \\
LG2 & $10-12$ & 170 & Rural \\
LG3 & $10-12$ & 170 & Rural \\
OG1 & $10-12$ & 190 & Rural \\
OG2 & $10-12$ & 190 & Rural \\
SG1 & $10-12$ & 1,300 & Urban \\
SG2 & $10-12$ & 1,300 & Urban \\
SG3 & $10-12$ & 1,300 & Urban \\
SG4 & $10-12$ & 1,300 & Urban \\
TG1 & $10-12$ & 1,200 & Urban \\
TG2 & $10-12$ & 1,200 & Urban \\
TG3 & $10-12$ & 1,200 & Urban \\
TG4 & $10-12$ & 1,200 & Urban \\
& & &
\end{tabular}

students were allowed to use their mobile phones in school and if so if they could connect to the school's Wi-Fi network.

If the teacher in the questionnaire reported that he/she was near a microwave oven in the lunch room and there also was a peak signal at the frequency band $2.400-2.4835 \mathrm{GHz}$, we excluded the measurement data during that time. The signal from the oven $(2.45 \mathrm{GHz})$ could be interpreted as a Wi-Fi signal by the exposimeter.

The information from the teachers, their work schedule, and questionnaire made it possible to relate different activities during the day with the measured values. The measurements took place during school time during the time period MarchNovember 2016.

For the measurements of RF radiation, the exposimeter EME-Spy 200 from Satimo (MVG Industries, Brest, France) with a valid calibration was used. The exposimeter measures 20 predefined frequency bands, as presented in Table 2. These cover the frequencies of most public RF radiation emitting devices currently used in Sweden. The exposimeter covers frequencies of 87-5,850 MHz. For frequency modulation (FM), TV3, TETRA, TV4\&5, Wi-Fi $2.4 \mathrm{GHz}$ and Wi-Fi $5 \mathrm{GHz}$, the lower detection limit is $0.01 \mathrm{~V} / \mathrm{m}\left(0.27 \mu \mathrm{W} / \mathrm{m}^{2}\right)$; for all other bands, the lower detection limit is $0.005 \mathrm{~V} / \mathrm{m}\left(0.066 \mu \mathrm{W} / \mathrm{m}^{2}\right)$. For all bands, the upper detection limit is $6 \mathrm{~V} / \mathrm{m}\left(95,544 \mu \mathrm{W} / \mathrm{m}^{2}\right)$. The sampling time was every fourth second.

The exposimeter measures different telecommunications protocols: FM-radio broadcasting; TV broadcasting; TETRA emergency services (police, rescue, etc.); GSM second generation mobile communications; UMTS third generation mobile communications, 3G; long-term evolution (LTE) fourth generation mobile communications standard, 4G; digital European cordless

TABLE 2 | Predefined measurement frequency bands of EME-Spy 200 exposimeter with frequency ranges.

\begin{tabular}{lrc}
\hline Frequency band & $\begin{array}{c}\text { Frequency } \\
\text { minimum (MHz) }\end{array}$ & $\begin{array}{c}\text { Frequency } \\
\text { maximum (MHz) }\end{array}$ \\
\hline FM & 87 & 107 \\
TV3 & 174 & 223 \\
TETRA I & 380 & 400 \\
TETRA II & 410 & 430 \\
TETRA III & 450 & 470 \\
TV4\&5 & 470 & 770 \\
LTE 800, 4G (DL) & 791 & 821 \\
LTE 800, 4G (UL) & 832 & 862 \\
GSM 900 + UMTS 900, 3G (UL) & 880 & 915 \\
GSM 900 + UMTS 900, 3G (DL) & 925 & 960 \\
GSM 1800 (UL) & 1,710 & 1,785 \\
GSM 1800 (DL) & 1,805 & 1,880 \\
DECT & 1,880 & 1,900 \\
UMTS 2100, 3G (UL) & 1,920 & 1,980 \\
UMTS 2100, 3G (DL) & 2,110 & 2,170 \\
Wi-Fi, 2.4 GHz & 2,400 & $2,483.5$ \\
LTE 2600, 4G (UL) & 2,500 & 2,570 \\
LTE 2600, 4G (DL) & 2,620 & 2,690 \\
WiMAX & 3,300 & 3,900 \\
Wi-Fi 5 GHz & 5,150 & 5,850 \\
& &
\end{tabular}

FM, frequency modulation; TV, television; LTE, long-term evolution; DL, downlink (transmission from base station to mobile phone); UL, uplink (transmission from mobile phone to base station); GSM, global system for mobile communications; UMTS, universal mobile telecommunications system; DECT, digital European cordless telecommunications; WiMAX, worldwide interoperability for microwave access. 
telecommunications (DECT) cordless telephone systems standard; Wi-Fi 2.4 and $5 \mathrm{GHz}$ wireless local area network (WLAN) protocol; worldwide interoperability for microwave access (WIMAX) wireless communication standard for high-speed voice, data, and Internet.

EME-Spy 200 utilizes 3-axis antenna to capture RF radiation from all possible directions. The unit reports the exposure after statistical processing, since each reported value is the sampling outcome, where many samples are collected and statistically processed including minimum, mean, median, and maximum values.

\section{Statistical Methods}

Means, medians, minimum, and maximum values in microwatts per square meter were calculated for all measured frequency bands and for total exposure, and box plots were constructed to illustrate the distribution of total exposure for all teachers. Values below the lower detection limit were treated as null (0). Total exposure was calculated as the sum of all measured frequency bands at each measured data point. Stata/SE 12.1 for Windows (StataCorp., College Station, TX, USA) was used for all calculations.

\section{RESULTS}

In total, 18 teachers carried the exposimeter during one to four working days in school. Every teacher measured from 6 to $31 \mathrm{~h}$ resulting in 5,321-28,238 readings for each teacher. In total, 230,100 readings were assessed corresponding to $255 \mathrm{~h}$ of measurements of RF radiation. The total results for each teacher are displayed in Table 3 with mean, median, minimum, and maximum values for a total of all RF radiation exposures.
The mean for each teacher ranged from 1.1 to $66.1 \mu \mathrm{W} / \mathrm{m}^{2}$ and medians from 0.6 to $51.8 \mu \mathrm{W} / \mathrm{m}^{2}$. The maximum values varied between 241.8 and $82,857.3 \mu \mathrm{W} / \mathrm{m}^{2}$. Figure 1 shows box plot for each of the 18 teachers with median values, boxes with the first and third quartiles and outliers. Table 4 shows all measurements divided into the 20 different frequency bands from 87 to $5,850 \mathrm{MHz}$. The highest peaks ranging from 43,938.7 to $82,856.6 \mu \mathrm{W} / \mathrm{m}^{2}$, came from mobile phones uplink from $4 \mathrm{G}$

TABLE 3 | Measurements of 18 teachers in seven schools in Sweden during March 14-November 10, 2016.

\begin{tabular}{lrrrrr}
\hline Teacher & \multicolumn{1}{c}{$\boldsymbol{n}$} & Mean & Median & Min & \multicolumn{1}{c}{ Max } \\
\hline MH1 & 13,992 & 17.6 & 2.3 & 0.0 & $61,471.9$ \\
MH2 & 11,418 & 24.3 & 4.3 & 0.0 & $43,942.6$ \\
MH3 & 8,466 & 1.1 & 0.6 & 0.0 & 241.8 \\
OH1 & 20,307 & 11.0 & 1.3 & 0.0 & $4,887.6$ \\
SH1 & 5,673 & 15.0 & 1.1 & 0.1 & $35,242.8$ \\
LG1 & 11,107 & 5.1 & 1.7 & 0.0 & $1,779.1$ \\
LG2 & 10,026 & 23.1 & 9.8 & 0.0 & $5,513.0$ \\
LG3 & 5,321 & 13.6 & 2.4 & 0.0 & $13,047.8$ \\
OG1 & 26,134 & 19.5 & 5.0 & 0.3 & $2,676.1$ \\
OG2 & 28,238 & 39.2 & 5.3 & 0.5 & $82,857.3$ \\
SG1 & 13,505 & 66.1 & 51.8 & 1.7 & 715.9 \\
SG2 & 14,734 & 22.9 & 7.8 & 0.2 & $8,845.2$ \\
SG3 & 13,018 & 23.7 & 16.2 & 0.0 & 700.0 \\
SG4 & 7,294 & 63.3 & 50.0 & 1.2 & $1,398.1$ \\
TG1 & 16,572 & 5.7 & 2.6 & 0.0 & $1,274.3$ \\
TG2 & 11,799 & 13.9 & 3.6 & 0.0 & $3,321.7$ \\
TG3 & 6,446 & 7.7 & 3.2 & 0.0 & $2,193.5$ \\
TG4 & 6,050 & 9.1 & 3.0 & 0.0 & 751.4 \\
Total & 230,100 & 22.5 & 4.6 & 0.0 & $82,857.3$ \\
& & & & &
\end{tabular}

Results are given by teacher, analyses of all data, and total exposure (microwatts per square meter) treating values at detection limit as 0 .

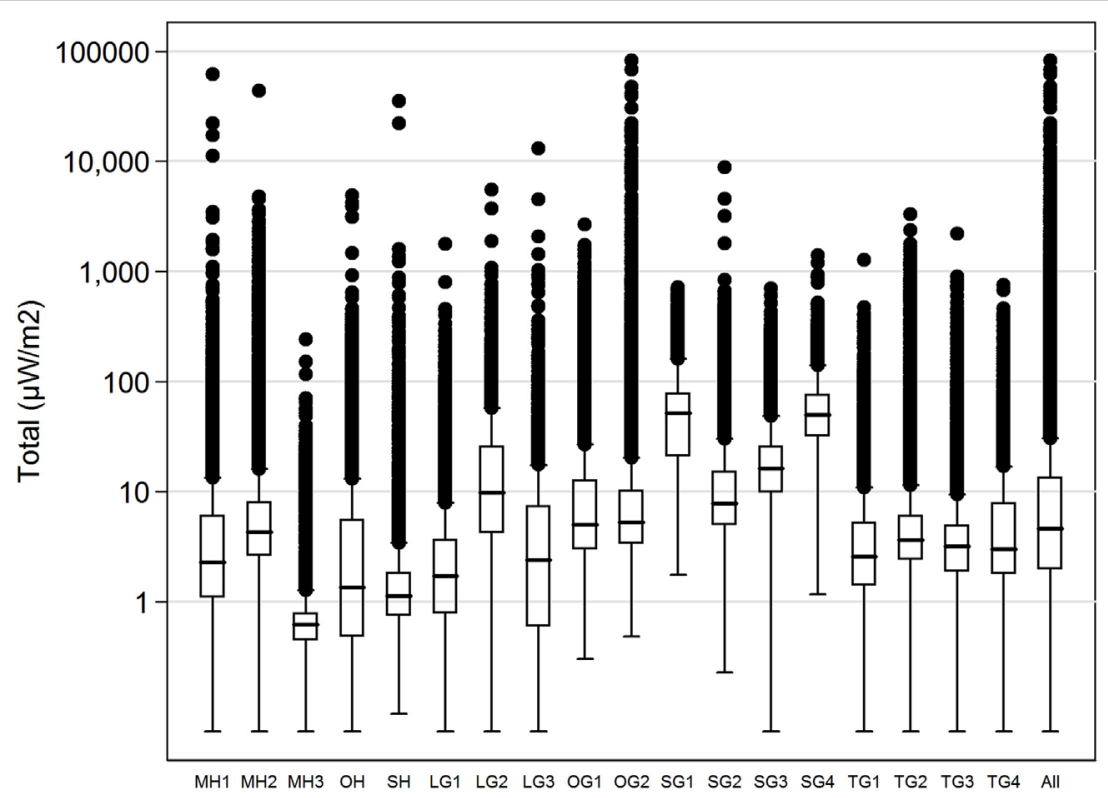

FIGURE 1 | Boxplot, total exposure (microwatts per square meter), all 18 teachers, logarithmic scale. The median is indicated by the black line inside each box; the bottom and top of the boxes represent the first and third quartiles; the end of the whiskers is calculated as $1.5 \times$ interquartile range. The points represent the outliers. 
$800 \mathrm{MHz}$, GSM 1,800 MHz, and 3G 2,100 MHz. The highest max downlink value, $3,285.9 \mu \mathrm{W} / \mathrm{m}^{2}$, came from $4 \mathrm{G} 800 \mathrm{MHz}$, while max for Wi-Fi $2.4 \mathrm{GHz}$ was $4,482.8 \mu \mathrm{W} / \mathrm{m}^{2}$ and $\mathrm{Wi}-\mathrm{Fi}$ $5 \mathrm{GHz} 3,321.4 \mu \mathrm{W} / \mathrm{m}^{2}$. All separate means added up to a total of $22.5 \mu \mathrm{W} / \mathrm{m}^{2}$. Total median was $4.6 \mu \mathrm{W} / \mathrm{m}^{2}$.

The teacher MH3 with the lowest mean, $1.1 \mu \mathrm{W} / \mathrm{m}^{2}$, taught in a classroom far from any Wi-Fi access point and had a wired connection to her own laptop for the education. The students used their laptops only in flight mode and mobile phones for students were banned during school time. The teachers in the school were allowed to carry and use their own mobile phones which can be seen by some higher peaks of GSM, 3G and $4 \mathrm{G}$ uplinks up to 151.1 $\mu \mathrm{W} / \mathrm{m}^{2}$, Table 5 and Figure 2 .

The teacher SG1 with the highest mean $66.1 \mu \mathrm{W} / \mathrm{m}^{2}$ and median $51.8 \mu \mathrm{W} / \mathrm{m}^{2}$ taught in a school with a weaker Wi-Fi network which entailed that both students and teachers connected their mobile phones to base stations outside school. Here, the different mobile phone networks had a high impact on the total RF radiation exposure, see Table 6 and Figure 3. Exposure from Wi-Fi 2.4 and $5 \mathrm{GHz}$ was low, partly because there was a wired connection to the teacher in each classroom.

The highest mean during a whole lesson, $107.3 \mu \mathrm{W} / \mathrm{m}^{2}$, is shown in Table 7 and Figure 4. The teacher OG1 stood right below an access point while using her Wi-Fi connected laptop during the lesson. None of the students used their laptops during this lesson. A short high mean came from a part of a lesson when another teacher, $\mathrm{MH} 2$, let the approximately 20 students in the class stream and watch YouTube videos. For a few minutes, the mean exposure went up to $396.6 \mu \mathrm{W} / \mathrm{m}^{2}$, mostly from Wi-Fi $2.4 \mathrm{GHz}$, Table 8 and Figure 5.

TABLE 4 | Measurements of 18 teachers in seven schools in Sweden during March 14-November 10, 2016, analyses of all data (microwatts per square meter) by frequency band treating values at detection limit as 0 .

\begin{tabular}{lcccr}
\hline Frequency band & Mean & Median & Min & Max \\
\hline FM & 0.7 & 0.0 & 0.0 & 345.7 \\
TV3 & 0.0 & 0.0 & 0.0 & 147.7 \\
TETRA I & 0.2 & 0.0 & 0.0 & 497.3 \\
TETRA II & 0.0 & 0.0 & 0.0 & 39.5 \\
TETRA III & 0.4 & 0.0 & 0.0 & 910.9 \\
TV4\&5 & 0.0 & 0.0 & 0.0 & 149.0 \\
LTE 800, 4G (DL) & 4.1 & 0.4 & 0.0 & $3,285.9$ \\
LTE 800, 4G (UL) & 4.0 & 0.0 & 0.0 & $82,856.6$ \\
GSM + UMTS 900, 3G (UL) & 0.2 & 0.0 & 0.0 & $2,874.5$ \\
GSM + UMTS 900, 3G (DL) & 3.0 & 0.5 & 0.0 & $2,063.5$ \\
GSM 1800 (UL) & 1.0 & 0.0 & 0.0 & $61,471.1$ \\
GSM 1800 (DL) & 0.0 & 0.0 & 0.0 & 60.5 \\
DECT & 0.0 & 0.0 & 0.0 & 328.7 \\
UMTS 2100, 3G (UL) & 0.3 & 0.0 & 0.0 & $43,938.7$ \\
UMTS 2100, 3G (DL) & 0.7 & 0.1 & 0.0 & 295.9 \\
Wi-Fi 2.4 GHz & 2.8 & 0.3 & 0.0 & $4,482.8$ \\
LTE 2600, 4G (UL) & 0.3 & 0.0 & 0.0 & $3,768.9$ \\
LTE 2600, 4G (DL) & 1.5 & 0.0 & 0.0 & 608.6 \\
WiMAX & 0.0 & 0.0 & 0.0 & 1.1 \\
Wi-Fi 5 GHz & 3.1 & 0.5 & 0.0 & $3,321.4$ \\
Total & 22.5 & 4.6 & 0.0 & $82,857.3$ \\
\hline
\end{tabular}

Totally 230,100 readings for each frequency band.

\section{DISCUSSION}

\section{Short Summary of Our Results}

Our measurements showed quite low-mean values from 1.1 to $66.1 \mu \mathrm{W} / \mathrm{m}^{2}$ with higher levels during lessons when laptops or mobile phones were actively used. The maximum values could be high when connecting to mobile phone base stations outside of the school building, up to $82,857.3 \mu \mathrm{W} / \mathrm{m}^{2}$ usually from uplink

TABLE 5 | Teacher MH3, November 9-10, 2016, analysis of all data (microwatts per square meter) by frequency band treating values at detection limit as 0 .

\begin{tabular}{lcccr}
\hline Frequency band & Mean & Median & Min & Max \\
\hline FM & 0.0 & 0.0 & 0.0 & 52.7 \\
TV3 & 0.0 & 0.0 & 0.0 & 0.3 \\
TETRA I & 0.0 & 0.0 & 0.0 & 0.0 \\
TETRA II & 0.0 & 0.0 & 0.0 & 0.0 \\
TETRA III & 0.0 & 0.0 & 0.0 & 0.9 \\
TV4\&5 & 0.0 & 0.0 & 0.0 & 0.0 \\
LTE 800 (DL) & 0.0 & 0.0 & 0.0 & 0.1 \\
LTE 800 (UL) & 0.0 & 0.0 & 0.0 & 31.5 \\
GSM + UMTS 900 (UL) & 0.0 & 0.0 & 0.0 & 13.0 \\
GSM + UMTS 900 (DL) & 0.5 & 0.5 & 0.0 & 14.9 \\
GSM 1800 (UL) & 0.1 & 0.0 & 0.0 & 151.5 \\
GSM 1800 (DL) & 0.0 & 0.0 & 0.0 & 1.7 \\
DECT & 0.0 & 0.0 & 0.0 & 1.0 \\
UMTS 2100 (UL) & 0.0 & 0.0 & 0.0 & 16.6 \\
UMTS 2100 (DL) & 0.1 & 0.0 & 0.0 & 3.2 \\
Wi-Fi 2.4 GHz & 0.3 & 0.0 & 0.0 & 111.5 \\
LTE 2600 (UL) & 0.1 & 0.0 & 0.0 & 129.6 \\
LTE 2600 (DL) & 0.0 & 0.0 & 0.0 & 0.9 \\
WiMAX & 0.0 & 0.0 & 0.0 & 0.0 \\
Wi-Fi 5 GHz & 0.0 & 0.0 & 0.0 & 2.1 \\
Total & 1.1 & 0.6 & 0.0 & 241.8 \\
& & & &
\end{tabular}

Totally 8,466 readings for each frequency band. The teachers in the school were allowed to bear and use their own mobile phones, but not the students. The teacher had a wired connection to her laptop while the students only used their laptops in flight mode in the classroom.

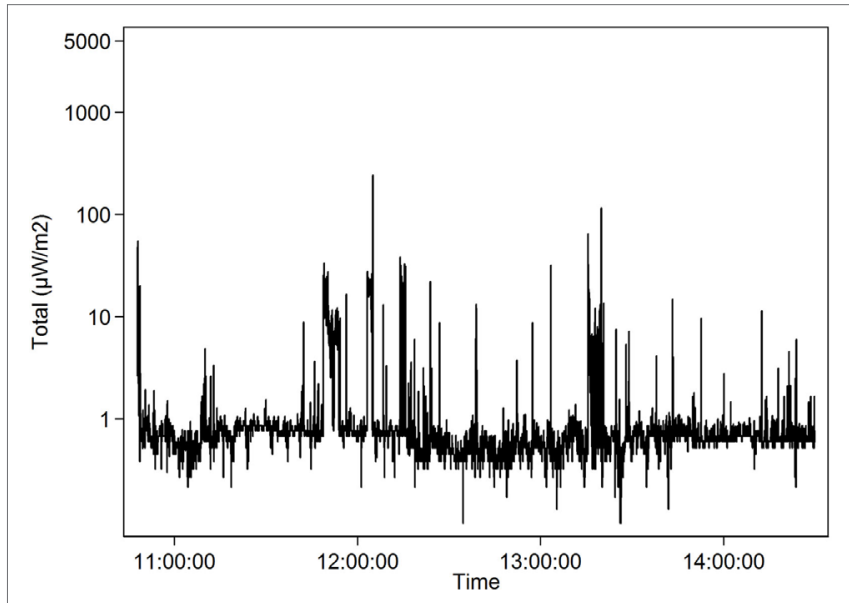

FIGURE 2 | Teacher MH3 who had a wired connection to her laptop and the students used their laptops only in flight mode in the classroom. The teachers in the school were allowed to bear and use their own mobile phones, but not the students. Radiofrequency mean exposure $1.1 \mu \mathrm{W} / \mathrm{m}^{2}$ (logarithmic scale) over 1 day (November 9, 2016). 
TABLE 6 | Teacher SG1, October 17-18, 2016, analysis of all data (microwatts per square meter) by frequency band treating values at detection limit as 0 .

\begin{tabular}{|c|c|c|c|c|}
\hline Frequency band & Mean & Median & Min & Max \\
\hline FM & 0.0 & 0.0 & 0.0 & 7.2 \\
\hline TV3 & 0.0 & 0.0 & 0.0 & 1.1 \\
\hline TETRA I & 0.9 & 0.6 & 0.0 & 36.3 \\
\hline TETRA ॥ & 0.3 & 0.0 & 0.0 & 39.5 \\
\hline TETRA III & 1.0 & 0.7 & 0.0 & 28.1 \\
\hline TV4\&5 & 0.0 & 0.0 & 0.0 & 4.5 \\
\hline LTE 800 (DL) & 27.5 & 16.6 & 0.0 & 676.5 \\
\hline LTE 800 (UL) & 0.1 & 0.0 & 0.0 & 105.0 \\
\hline GSM + UMTS 900 (UL) & 0.0 & 0.0 & 0.0 & 1.7 \\
\hline GSM + UMTS 900 (DL) & 10.7 & 8.3 & 0.1 & 173.8 \\
\hline GSM 1800 (UL) & 0.3 & 0.0 & 0.0 & 371.0 \\
\hline GSM 1800 (DL) & 0.3 & 0.3 & 0.0 & 2.5 \\
\hline DECT & 0.0 & 0.0 & 0.0 & 42.8 \\
\hline UMTS 2100 (UL) & 0.0 & 0.0 & 0.0 & 8.3 \\
\hline UMTS 2100 (DL) & 3.3 & 2.9 & 0.0 & 52.7 \\
\hline Wi-Fi $2.4 \mathrm{GHz}$ & 1.6 & 0.6 & 0.0 & 229.3 \\
\hline LTE 2600 (UL) & 0.0 & 0.0 & 0.0 & 43.5 \\
\hline LTE 2600 (DL) & 16.0 & 9.5 & 0.0 & 343.8 \\
\hline WiMAX & 0.0 & 0.0 & 0.0 & 0.0 \\
\hline Wi-Fi 5 GHz & 4.0 & 1.3 & 0.0 & 566.2 \\
\hline Total & 66.1 & 51.8 & 1.7 & 715.9 \\
\hline
\end{tabular}

Totally 13,505 readings for each frequency band. Results for a school with a weaker wireless fidelity network. Both students and teachers connected their mobile phones to base stations outside school.

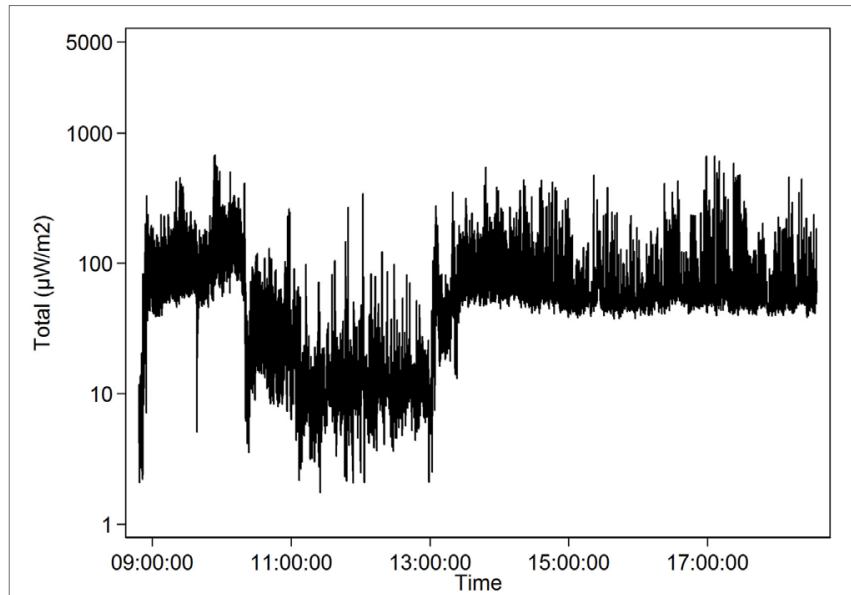

FIGURE 3 | Teacher SG1. Total radiofrequency radiation (mean exposure $66.1 \mu \mathrm{W} / \mathrm{m}^{2}$, logarithmic scale) over 1 day (October 17, 2016). Results for a school with a weaker wireless fidelity network. Both students and teachers connected their mobile phones to base stations outside school.

from GSM 1800, 3G or 4G. Maximum downlink from the same base stations was $3,285.9 \mu \mathrm{W} / \mathrm{m}^{2}$. Maximum peaks from $\mathrm{Wi}-\mathrm{Fi}$ 2.4 GHz were $4,482.8 \mu \mathrm{W} / \mathrm{m}^{2}$ and from Wi-Fi $5 \mathrm{GHz} 3,321.4 \mu \mathrm{W} /$ $\mathrm{m}^{2}$. Total means for all teachers were for Wi-Fi $2.4 \mathrm{GHz} 2.8 \mu \mathrm{W} /$ $\mathrm{m}^{2}$ and for $5 \mathrm{GHz} 3.1 \mu \mathrm{W} / \mathrm{m}^{2}$.

\section{RF Radiation Exposure in Sweden and in Schools in Other Countries}

The levels of RF radiation have increased considerably during recent years both outdoor and indoor due to emergence of new
TABLE 7 | Teacher OG1, May 31, 2016, 8:00-10:00, analysis of all data (microwatts per square meter) by frequency band treating values at detection limit as 0.

\begin{tabular}{|c|c|c|c|c|}
\hline Frequency band & Mean & Median & Min & Max \\
\hline FM & 0.1 & 0.0 & 0.0 & 6.1 \\
\hline TV3 & 0.0 & 0.0 & 0.0 & 1.4 \\
\hline TETRA I & 1.1 & 1.1 & 0.0 & 15.7 \\
\hline TETRA II & 0.0 & 0.0 & 0.0 & 0.0 \\
\hline TETRA III & 0.0 & 0.0 & 0.0 & 0.0 \\
\hline TV4\&5 & 0.0 & 0.0 & 0.0 & 0.0 \\
\hline LTE 800 (DL) & 1.5 & 1.3 & 0.1 & 14.1 \\
\hline LTE 800 (UL) & 0.1 & 0.0 & 0.0 & 23.4 \\
\hline GSM + UMTS 900 (UL) & 0.0 & 0.0 & 0.0 & 3.2 \\
\hline GSM + UMTS 900 (DL) & 2.0 & 1.9 & 0.1 & 5.9 \\
\hline GSM 1800 (UL) & 0.0 & 0.0 & 0.0 & 0.0 \\
\hline GSM 1800 (DL) & 0.0 & 0.0 & 0.0 & 0.0 \\
\hline DECT & 0.0 & 0.0 & 0.0 & 0.0 \\
\hline UMTS 2100 (UL) & 0.0 & 0.0 & 0.0 & 0.4 \\
\hline UMTS 2100 (DL) & 0.0 & 0.0 & 0.0 & 0.4 \\
\hline Wi-Fi $2.4 \mathrm{GHz}$ & 54.4 & 33.3 & 0.1 & $1,727.5$ \\
\hline LTE 2600 (UL) & 0.0 & 0.0 & 0.0 & 0.9 \\
\hline LTE 2600 (DL) & 0.0 & 0.0 & 0.0 & 0.4 \\
\hline WiMAX & 0.0 & 0.0 & 0.0 & 0.2 \\
\hline Wi-Fi 5 GHz & 48.0 & 11.6 & 0.0 & $1,540.2$ \\
\hline Total & 107.3 & 62.7 & 1.6 & $1,742.3$ \\
\hline
\end{tabular}

Totally 1,801 readings for each frequency band. The highest mean level during a whole lesson in this study was recorded when the teacher stood right below an access point while using her wireless fidelity connected laptop during the lesson.

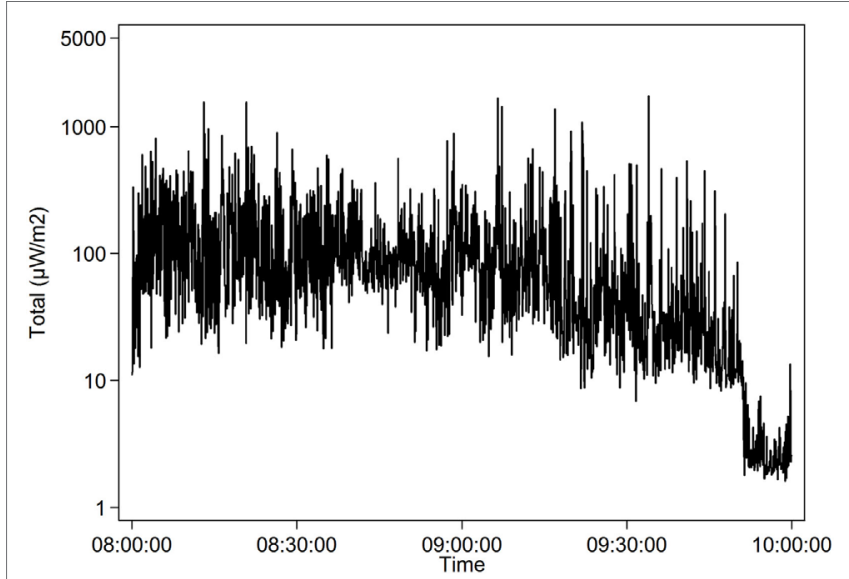

FIGURE 4 | The highest mean level (107.3 $\mu \mathrm{W} / \mathrm{m}^{2}$, logarithmic scale) during a whole lesson was recorded when the teacher OG1 stood right below an access point while using her wireless fidelity connected laptop (May 31, 2016).

telecommunication technologies and protocols. Measurements of outdoor exposure with a car-based measuring system done in 2013 in Sweden showed a median power density for RF fields between $30 \mathrm{MHz}$ to $3 \mathrm{GHz}$ to be $16 \mu \mathrm{W} / \mathrm{m}^{2}$ in rural areas, $270 \mu \mathrm{W} / \mathrm{m}^{2}$ in urban areas, and $2,400 \mu \mathrm{W} / \mathrm{m}^{2}$ in city areas (72). Areas with high exposure to RF radiation were measured with an EME-Spy 200 exposimeter in Stockholm Central Railway Station where the mean total RF radiation level varied between 2,817 and $4,891 \mu \mathrm{W} / \mathrm{m}^{2}\left(\min 5.8, \max 155,263.4 \mu \mathrm{W} / \mathrm{m}^{2}\right)$ for each walking round (73). In the Old Town in Stockholm, the total 
TABLE 8 | Teacher MH2, November 8, 2016, 15:20-15:25, analysis of all data (microwatts per square meter) by frequency band treating values at detection limit as 0 .

\begin{tabular}{lrrrr}
\hline Frequency band & Mean & Median & Min & Max \\
\hline FM & 0.0 & 0.0 & 0.0 & 1.0 \\
TV3 & 0.0 & 0.0 & 0.0 & 0.4 \\
TETRA I & 0.0 & 0.0 & 0.0 & 0.0 \\
TETRA II & 0.0 & 0.0 & 0.0 & 0.0 \\
TETRA III & 0.0 & 0.0 & 0.0 & 0.0 \\
TV4\&5 & 0.0 & 0.0 & 0.0 & 0.0 \\
LTE 800 (DL) & 0.0 & 0.0 & 0.0 & 0.0 \\
LTE 800 (UL) & 0.0 & 0.0 & 0.0 & 0.0 \\
GSM + UMTS 900 (UL) & 0.1 & 0.0 & 0.0 & 4.0 \\
GSM + UMTS 900 (DL) & 0.0 & 0.0 & 0.0 & 0.2 \\
GSM 1800 (UL) & 4.4 & 0.0 & 0.0 & 165.8 \\
GSM 1800 (DL) & 0.0 & 0.0 & 0.0 & 0.1 \\
DECT & 0.0 & 0.0 & 0.0 & 0.0 \\
UMTS 2100 (UL) & 0.0 & 0.0 & 0.0 & 1.1 \\
UMTS 2100 (DL) & 0.0 & 0.0 & 0.0 & 0.0 \\
Wi-Fi 2.4 GHz & 365.7 & 136.2 & 0.6 & $3,606.2$ \\
LTE 2600 (UL) & 22.6 & 8.3 & 0.0 & 172.5 \\
LTE 2600 (DL) & 0.0 & 0.0 & 0.0 & 0.0 \\
WiMAX & 0.0 & 0.0 & 0.0 & 0.1 \\
Wi-Fi 5 GHz & 3.7 & 2.0 & 0.8 & 11.6 \\
Total & 396.6 & 153.8 & 3.0 & $3,650.3$ \\
\hline
\end{tabular}

Totally 76 readings for each frequency band. The approximately 20 students in the class streamed and watched YouTube videos during a part of the lesson.

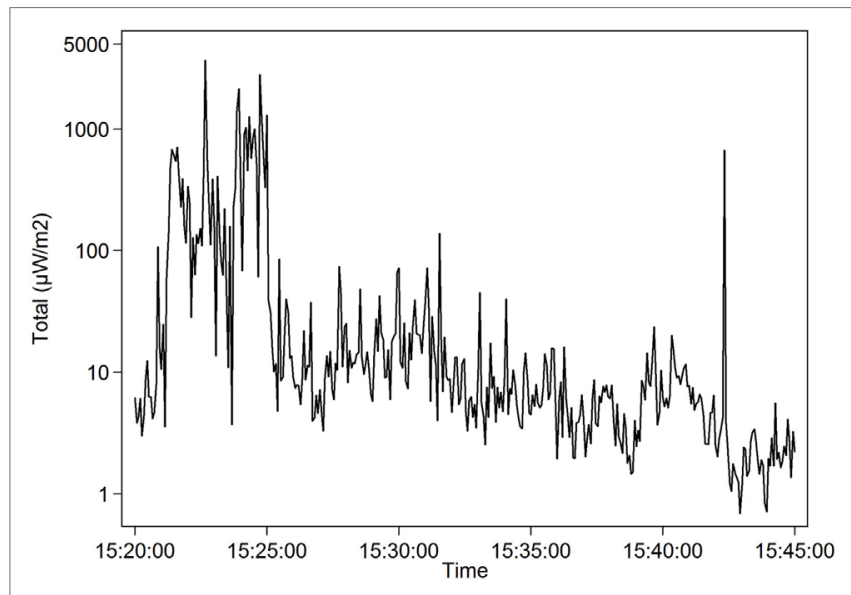

FIGURE 5 | Teacher MH2 (November 8, 2016; 15:20-15:45, logarithmic scale). Radiofrequency radiation when students during a part of the lesson streamed and watched YouTube videos. For the time period 15:20-15:25, the mean exposure was $396.6 \mu \mathrm{W} / \mathrm{m}^{2}$.

$\mathrm{RF}$ radiation varied between a mean of $404 \mu \mathrm{W} / \mathrm{m}^{2}(\min 20.4$, $\max 4,088 \mu \mathrm{W} / \mathrm{m}^{2}$ ) on the streets around the Supreme Court, $756 \mu \mathrm{W} / \mathrm{m}^{2}\left(\min 0.3, \max 50,967 \mu \mathrm{W} / \mathrm{m}^{2}\right)$ around the Royal Castle, and $24,277 \mu \mathrm{W} / \mathrm{m}^{2}\left(\min 257, \max 173,302 \mu \mathrm{W} / \mathrm{m}^{2}\right)$ at Järntorget, a popular square with shops and outdoor restaurants (74).

A study was performed in a laboratory in the United Kingdom, which simulated a typical classroom with laptops but without any students. The laptops were set into the transmission mode and the exposure from 15 laptops and $12 \mathrm{Wi}-\mathrm{Fi}$ access points was measured. The measured maximum power density values were
$22,000 \mu \mathrm{W} / \mathrm{m}^{2}$ at $0.5 \mathrm{~m}$ from the laptops and $87,000 \mu \mathrm{W} / \mathrm{m}^{2}$ at $0.5 \mathrm{~m}$ from access points decreasing to 4,000 and $18,000 \mu \mathrm{W} / \mathrm{m}^{2}$ at a $1 \mathrm{~m}$ distance, respectively (75).

A measurement study in schools in Belgium and Greece showed a total maximum value from all contributors of RF-EMFs of $1.6 \mathrm{~V} / \mathrm{m}\left(6,790 \mu \mathrm{W} / \mathrm{m}^{2}\right)$ and $1.66 \mathrm{~V} / \mathrm{m}\left(7,310 \mu \mathrm{W} / \mathrm{m}^{2}\right)$, respectively, and an average value of about $0.4 \mathrm{~V} / \mathrm{m}\left(400 \mu \mathrm{W} / \mathrm{m}^{2}\right)$ in both countries. In Belgium, it was mostly GSM 900 and the FM-radio signal that gave the highest exposure and in Greece GSM 1800 and 3G. None of the participating schools had education that involved the use of laptop by every student in the class. The exposure from Wi-Fi was low, in Belgium $6.6 \mu \mathrm{W} / \mathrm{m}^{2}$ and in Greece $21.4 \mu \mathrm{W} / \mathrm{m}^{2}$, Table 9 (76).

In a study from 2010 to 2011 in Slovenia, 18 school children between the ages of 5 and 17 wore portable exposimeters day and night for an average of $69 \mathrm{~h}$ in total. High-maximum values of $\mathrm{RF}$ radiation were recorded for DECT, which exceeded the exposimeter's upper measurable limit of $5 \mathrm{~V} / \mathrm{m}\left(66,300 \mu \mathrm{W} / \mathrm{m}^{2}\right)$, GSM with $3.46 \mathrm{~V} / \mathrm{m}\left(31,800 \mu \mathrm{W} / \mathrm{m}^{2}\right)$, and Wi-Fi $2.47 \mathrm{~V} / \mathrm{m}$ $\left(16,180 \mu \mathrm{W} / \mathrm{m}^{2}\right)$. Most measurements of other frequencies for all the 18 children's measurements showed low-average values, only barely over the detection limit on $0.05 \mathrm{~V} / \mathrm{m}\left(6.6 \mu \mathrm{W} / \mathrm{m}^{2}\right)$. The sample's highest personal average value for $\mathrm{Wi}-\mathrm{Fi}$ was $0.08 \mathrm{~V} / \mathrm{m}$ $\left(16.9 \mu \mathrm{W} / \mathrm{m}^{2}\right)$ for GSM $0.20 \mathrm{~V} / \mathrm{m}\left(106.1 \mu \mathrm{W} / \mathrm{m}^{2}\right)$ and for DECT $0.24 \mathrm{~V} / \mathrm{m}\left(152.8 \mu \mathrm{W} / \mathrm{m}^{2}\right)(77)$.

A study in Belgium focused on schools with Wi-Fi and measured in five schools an average of $0.24 \mathrm{~V} / \mathrm{m}\left(152.8 \mu \mathrm{W} / \mathrm{m}^{2}\right)$ and peaks up to $3.21 \mathrm{~V} / \mathrm{m}\left(27,347 \mu \mathrm{W} / \mathrm{m}^{2}\right)$ for Wi-Fi signals (78).

In 2013-2014, 90 adolescents aged 13-17 years in Switzerland carried a portable exposimeter, ExpoM-RF, in a hip bag for 3 days. They also filled in a time-activity diary on a smartphone. The exposimeter measured every fourth second in 12 different frequency bands between $620 \mathrm{MHz}$ and $2.4 \mathrm{GHz}$. Of the 90 students, 34 had WLANs in school and 86 of 90 had WLAN at home. All students had their own mobile phone and most, 86 , had their own smartphone. Total average RF radiation exposure was $63.2 \mu \mathrm{W} / \mathrm{m}^{2}$. Main sources were from mobile phones (67.2\%) and from mobile phone base stations (19.8\%). WLAN at home and at school was only a small part of the personal exposure $(3.5 \%)$, mean measurements in schools were $59.7 \mu \mathrm{W} / \mathrm{m}^{2}$, in trains $537.4 \mu \mathrm{W} / \mathrm{m}^{2}$, in busses $663.5 \mu \mathrm{W} / \mathrm{m}^{2}$, and in cars $832.2 \mu \mathrm{W} / \mathrm{m}^{2}$. In all these locations, mobile phones uplink of $900,1,800$, and $1,900 \mathrm{MHz}$ were the main contributor. To have WLAN at home and at school showed lower total average exposure than with no WLAN at home and/or school (79).

In a study in Slovenia during 2014-2015, 49 pairs of child and parent carried an ExpoM-RF exposimeter for 3 days which also recorded geographic location using GPS. They also kept activity diaries on smartphones Average personal RF radiation exposure was $0.21 \mathrm{~V} / \mathrm{m}\left(117 \mu \mathrm{W} / \mathrm{m}^{2}\right)$ at home, $0.18 \mathrm{~V} / \mathrm{m}\left(85.9 \mu \mathrm{W} / \mathrm{m}^{2}\right)$ at school, and $0.31 \mathrm{~V} / \mathrm{m}\left(255.0 \mu \mathrm{W} / \mathrm{m}^{2}\right)$ at work. The main contributions from different sources were $0.11 \mathrm{~V} / \mathrm{m}\left(32.1 \mu \mathrm{W} / \mathrm{m}^{2}\right)$ from uplink, $0.18 \mathrm{~V} / \mathrm{m}\left(85.9 \mu \mathrm{W} / \mathrm{m}^{2}\right)$ from downlink, $0.15 \mathrm{~V} / \mathrm{m}$ $\left(59.7 \mu \mathrm{W} / \mathrm{m}^{2}\right)$ from broadcasting, and $0.08 \mathrm{~V} / \mathrm{m}\left(16.9 \mu \mathrm{W} / \mathrm{m}^{2}\right)$ from WLAN (80).

In Turkey, measurements were made twice in May and June 2016 in 92 schools with PMM 8053 and Narda SRM-3006 
TABLE 9 | Measurement studies in schools.

\begin{tabular}{|c|c|c|c|c|}
\hline Reference & Country & $\begin{array}{l}\text { Means for all RF radiation in } \mu \mathrm{W} / \mathrm{m}^{2} \\
\text { (lowest and highest personal mean) }\end{array}$ & $\begin{array}{c}\text { Means for } \mathrm{Wi}-\mathrm{Fi} \text { in } \\
\mu \mathrm{W} / \mathrm{m}^{2} \text { (lowest and } \\
\text { highest personal mean) }\end{array}$ & $\begin{array}{l}\text { Means in } \mu \mathrm{W} / \mathrm{m}^{2} \text { for other RF sources } \\
\text { (lowest and highest personal mean) }\end{array}$ \\
\hline \multirow[t]{2}{*}{ Vermeeren et al. ${ }^{a}(76)$} & Belgium & 403.6, mostly FM-radio and GSM 900 & 6.6 & $\begin{array}{l}\text { FM } 223.2 \\
\text { GSM } 90076.7\end{array}$ \\
\hline & Greece & 424.6, mostly GSM 1800 and 3G & 21.4 & $\begin{array}{l}\text { GSM } 1800193.4 \\
\text { UMTS } 44.8\end{array}$ \\
\hline Verloock et al. ${ }^{a}(78)$ & Belgium & 325.1 & 152.8 & \\
\hline \multirow[t]{5}{*}{ Kurnaz et al. a (81) } & Turkey & $\begin{array}{c}\text { Mostly LTE } 800, \text { GSM 900,1800, } \\
\text { UMTS } 2100\end{array}$ & 1.5 & \\
\hline & May 2016 & 229.2 & & \\
\hline & June 2016 & 171.3 & & \\
\hline & School with highest & & & \\
\hline & exposure & 29.944 .7 & & \\
\hline Karipidis et al. (83) & Australia & & $50-67$ & \\
\hline \multicolumn{5}{|c|}{ Body-borne exposimeters } \\
\hline \multirow[t]{2}{*}{ Valic et al. ${ }^{\text {a }}(77)$} & Slovenia & & $9.5(6.6-16.9)$ & GSM 13.0 (6.6-106.1) \\
\hline & Detection limit 6.6 & & & DECT 13.0 (6.6-152.8) \\
\hline Gajšek et al. $^{a}(80)$ & Slovenia & 85.9 & 16.9 & \\
\hline Roser et al. (79) & Switzerland & 59.7 & $2.2(1.0-7.4)$ & \\
\hline The present study & Sweden & $22.5(1.1-66.1)$ & $\begin{array}{l}2.4 \mathrm{GHz}: 2.8(0.2-8.9) \\
5 \mathrm{GHz}: 3.1(0-10.4)\end{array}$ & $\begin{array}{l}\text { Downlink for } \\
\text { LTE } 8004.1(0-27.5) \\
\text { GSM + UMTS } 9003.0(0.1-28.1) \\
\text { UMTS } 21000.7(0-3.3) \\
\text { LTE } 26001.5(0-16.0)\end{array}$ \\
\hline
\end{tabular}

aln these papers, the radiofrequency (RF) radiation was measured in volts per meter. To make the measured values comparable electric field strength (E) in volts per meter have been converted to power density (S) in microwatts per square meter with the formula $S=0.002654 \times E^{2} \times 10^{6}$.

exposimeters. The mean exposure was $0.2939 \mathrm{~V} / \mathrm{m}(229.2 \mu \mathrm{W} /$ $\left.\mathrm{m}^{2}\right)$ in May and $0.2541 \mathrm{~V} / \mathrm{m}\left(171.3 \mu \mathrm{W} / \mathrm{m}^{2}\right)$ in June. The main contributors were LTE $800 \mathrm{MHz}$, GSM $900 \mathrm{MHz}$, and GSM $1800 \mathrm{MHz}$. WLAN constituted a very small part with an average on $0.024 \mathrm{~V} / \mathrm{m}\left(1.5 \mu \mathrm{W} / \mathrm{m}^{2}\right)(81)$.

In a study in Melbourne, Australia in 2015, environmental RF radiation was measured in 20 different kindergartens and by 10 children aged 4-5 years who carried an exposimeter in a small bag attached around the chest. The exposimeter ExpoM-RF 64 could measure 16 frequency bands from $88 \mathrm{MHz}$ to $5.8 \mathrm{GHz}$. There was a clear difference between kindergartens situated less than $300 \mathrm{~m}$ from base stations and those located more than $300 \mathrm{~m}$ away. The total median environmental exposure was $258 \mathrm{mV} / \mathrm{m}(176.6 \mu \mathrm{W} /$ $\mathrm{m}^{2}$ ) for kindergartens situated less than $300 \mathrm{~m}$ from a base station compared with $75 \mathrm{mV} / \mathrm{m}\left(14.9 \mu \mathrm{W} / \mathrm{m}^{2}\right)$ for those situated more than $300 \mathrm{~m}$ from a base station. The three highest contributors were GSM $900 \mathrm{MHz}$ downlink and uplink and UMTS $2100 \mathrm{MHz}$ downlink. The median personal exposure for all the 10 children was $81 \mathrm{mV} / \mathrm{m}\left(16.9 \mu \mathrm{W} / \mathrm{m}^{2}\right)$ ranging from $31 \mathrm{mV} / \mathrm{m}\left(2.5 \mu \mathrm{W} / \mathrm{m}^{2}\right)$ for the child with lowest exposure in a kindergarten more than $300 \mathrm{~m}$ away from a base station to $255 \mathrm{mV} / \mathrm{m}\left(172.5 \mu \mathrm{W} / \mathrm{m}^{2}\right)$ for a child with the highest exposure in a kindergarten less than $300 \mathrm{~m}$ away from a base station (82).

Another study in Australia measured during 2016 in 23 schools with Wi-Fi networks with a Narda SRM-3006 Selective Radiation Meter with three separate axial probes from $9 \mathrm{kHz}$ to $6 \mathrm{GHz}$. In only two schools, students were present and in one school a group of teachers were working with Wi-Fi devices. In the empty classrooms, one or more laptops were in active mode downloading large files or browsing the Internet. The average exposure, while walking through the classroom for $10 \mathrm{~min}$, varied between 50 and $67 \mu \mathrm{W} / \mathrm{m}^{2}$ for $\mathrm{Wi}-\mathrm{Fi}$ in idle or active conditions for the 20 schools and the maximum exposure varied between 840 and $1,100 \mu \mathrm{W} / \mathrm{m}^{2}$. The median duty cycle was for $2.45 \mathrm{GHz} 6.3 \%$ and for $5 \mathrm{GHz} 2.4 \%$. The duty cycle is the proportion of time that Wi-Fi transmits RF signals. One conclusion of the study was that the personal exposure of each student to Wi-Fi will be largely dominated by the closest access point or client device rather than the total number of access points and devices around the school (83). Table 9 shows a comprehensive view of the measurements from the above studies compared with the present study.

The often short duty cycle in Wi-Fi networks can give low-average measured values but still consist of high peaks. Khalid et al. measured in schools in United Kingdom when students worked on web-based learning applications, surfed the Internet, downloaded files, and watched videos. The duty cycle for the children's laptops varied from 0.02 to $0.91 \%$, average $0.08 \%$, and for the access points $1.0-11.7 \%$, average $4.79 \%$. The transmissions from Wi-Fi devices "consist of trains of pulses of RF energy ranging in duration from a few tenths of a milliseconds to about $10 \mathrm{~ms}$, depending on the amount of data being carried by a burst." Operating with maximal duty factors in a classroom with 30 laptops and an access point at a distance of only $0.5 \mathrm{~m}$ could give a maximal personal exposure of $16,600 \mu \mathrm{W} / \mathrm{m}^{2}(84)$. 
Joseph et al. measured duty cycles of WLANs at 179 locations in urban areas, homes, and offices while the users surfed the Internet, downloaded YouTube videos, etc. The median duty cycle of all WLAN measurements was $1.4 \%$. The actual duty cycle varied a lot depending on the load on the network and the network speed. The maximum measured duty cycle was $93.6 \%$ for file transfer over a slow network. Surfing and audio streaming require less Mbits and have lower duty cycles, usually below 3.2\% (85).

The different modulations result in signals with different spectral characteristics within the channel for the device. If these modulations would be shown to be important variables in accessing risk, the need for RF radiation protection would probably change (86).

The importance to minimize the users' exposure to the EMFs while retaining the network connectivity was discussed in a study with different wireless devices. Connection to the network via Enhanced Data rates for GSM Evolution or General Packet Radio Services technologies showed the strongest fields measured with a 14-point measurement model on the body. WLAN connection or $3 \mathrm{G}$ within excellent network reception showed significantly less exposure (87). Another study showed higher mean and maximum values for $3 \mathrm{G} / 4 \mathrm{G}$, especially with long distances to base stations (88).

\section{Limitations Due to Method of Measurements}

Our results were based on limited numbers and should therefore be interpreted with caution. For definite conclusions larger studies are needed including more schools and teachers.

The present study used an EME-Spy 200 exposimeter for measurements, see also our earlier studies $(73,74)$. Because samples were taken every fourth second, technologies with large differences between mean and peak might not have been exactly evaluated, an inherent limitation of the exposimeter, which is intended to determine the dosage. For example, exposures from the Wi-Fi access points may have been undervalued with the used exposimeter. Generally, peak signal level measurement data are interesting when discussing the non-thermal health effects of RF radiation. Also the duty cycle, that was not possible to measure in our study, is of importance. A short duty cycle, even if the RF radiation is very high during emission, will usually give a lowmean value. A long duty cycle will more correctly correspond to the peaks in the transmission and give a higher mean value.

The shielding effect from the body of a person carrying an exposimeter can be considerable when comparing a body-borne exposimeter with an exposimeter mounted on a car roof (89), or compared with an exposimeter placed in the middle of a room (90). This has to be considered when analyzing any exposimetric measurements. To use an exposimeter with three-axis antenna, like the EME-Spy 200 in the present study, may minimize body shielding according to Bhatt et al. (91).

The teachers carrying the exposimeter are used as proxies for the students' exposure in schools. They often move around in the classroom and may in this way have been exposed to both higher and lower values of RF radiation. Depending on where access points are located and how long time the connection to the Internet is used, the exposure can differ between students sitting nearby each other using laptops. The teachers' exposure is also valuable to know since they are exposed for as long as the students each day. A case study describes both students and teachers, who have shown symptoms and become sensitive to RF radiation from Wi-Fi sending devices in school (92).

\section{Risk Management}

The measurements show that letting the students connect their own mobile phones to the school's Wi-Fi network decreases the exposure levels compared with connecting mobile phones to GSM, $3 \mathrm{G}$ and $4 \mathrm{G}$ base stations. To not allow students to bring mobile phones to school or collect these in turned off mode every morning decreases the exposure even more.

It is essential to consider the duty cycle-the period during which the Wi-Fi devices are sending. A high-effective Wi-Fi network minimizes the duty cycles, the time the children are exposed and the average exposure value while the students use the Internet, but the background RF radiation may be higher with high peaks and this may influence well-being, especially for electromagnetic hypersensitive persons. The highest peaks in our study (see Table 4) came from the mobile phone's uplink to the base stations outside school. If the teacher or student keeps their mobile phone in the pocket close to the body, the exposure can be considerable every time the mobile phone connects for updating data. Activated Wi-Fi in mobile phones usually connects very frequently to the Internet (often every 5-10 s).

The largest impact in reducing students' exposure to wireless radiation can be observed when wired network connections are used instead of wireless connections. While wireless connections are the cause for the students' exposure to RF radiation, wired connections are not accompanied by such radiation. Even when wired connections are used in computers, wireless connections may still be active and in use by students' and teachers' mobile phones. A strategy to reduce the exposure to RF radiation would require (1) removing mobile phones from the learning environment or (2) to switch these into flight mode, which deactivates all wireless transmissions or (3) to switch off the wireless connections on the phone (Wi-Fi, mobile data), and leaving on only the mobile telephony voice communication connection (GSM or UMTS or LTE).

To download large files and stream videos, as for the students of teacher MH2, see Figure 5, will give high exposure to RF radiation. In contrast, surfing on the Internet or working mostly on already downloaded programs gives lower exposure. The RF radiation from Wi-Fi could be minimized by using wired connections for both the teachers and students.

Higher exposure to wireless radiation was also encountered in classrooms where $\mathrm{Wi}$-Fi access points were positioned in the classroom as in contrast to schools where the access points were positioned further away from the students. An exposure reduction solution would be to place the access points outside from classrooms. The RF radiation may have to be stronger, though, if the signals from the $\mathrm{Wi}$-Fi access point outside a classroom have more difficulty to reach the clients' devices through a thick wall of concrete. Also the radiation from the access point should be directed only toward the client's device, relieving other people in the vicinity from the unnecessary radiation. 
The teacher OG1 in Figure 4 and Table 7, standing right under an access point while using a laptop during the lesson led to higher Wi-Fi exposure compared with the schools which had wired connection to the Internet for the teacher in the classroom (Tables 5 and 6).

Since the wireless radiation is always active, even if the devices are not in use, this also contributes to the exposure budget of the students and teachers. An option to reduce the exposure would be to activate the wireless access points only for the period when the network connection is really needed for study purposes.

Several of the schools participating in our measurement study were situated in small towns or outside the city center. The environmental exposure from base stations located at the surrounding buildings (downlink) was low compared with our measurements in Stockholm city $(73,74)$. Thus, with low-outdoor exposure there will be less RF radiation indoors. Reducing children's exposure to $\mathrm{RF}$ radiation would require removing mobile phone base station antennas from adjacent buildings. In case of finding locations for new schools, these should be located away from the mobile phone base stations.

Students' use of mobile devices for social networking and other non-study activities that are irrelevant for learning goals during school time may contribute to a significant portion of the wireless communications. An exposure reduction solution would call for rules disallowing the usage of wireless connections for any other use than school-related tasks.

A few smaller schools in Sweden use only wired connection to the Internet. More and more schools have decided to ban mobile phones during the school day to avoid distraction during lessons and to increase social interactions in breaks. Thereby also the RF radiation is reduced in the school. It is important to get all the advantages from ICT and in the same time prevent any potential long-term health effects. The teacher MH3 in Figure 2 had the lowest mean, median, and maximum values in our study. She had lessons in a classroom far from Wi-Fi access points, students' mobile phones were not allowed, the teacher's laptop had a wired connection, and the students' laptops were in flight mode.

There is a complex picture about well-being and the use of laptops, tablets, and smartphones in schools and at home. It is unclear to what extent the screen time, the more sedentary activities, multitasking, lack of sleep, and changing of everyday life due to the technical development, that influence the physical and mental well-being. However, the RF radiation from wireless devices may also have a smaller or more pronounced impact on the well-being of children and adolescents. There seems to be a big difference in sensibility to RF radiation between individuals both among humans and animals in studies $(92,93)$.

Since children are obliged by law to attend school, the safe environment with respect to physical hazards is of utmost importance. Our study showed low-average exposure compared with our measurements in city streets and squares in Stockholm where the average exposure often is around $1,000 \mu \mathrm{W} / \mathrm{m}^{2}$. All measured values in the schools were far below ICNIRP's reference values (26), but most total mean measured levels were above the precautionary target level of $3-6 \mu \mathrm{W} / \mathrm{m}^{2}$ as proposed by the Bioinitiative Report (28). It is unclear whether it is the average level that have the most impact on health or if the peaks and the length of
TABLE 10 | The following actions are examples of methods to reduce children's exposure to $\mathrm{RF}$ radiation in schools.

1. Wired connection to both teachers and students and no wireless networks or devices in school is the optimal choice. If this is not possible:

2. Wired connection to each classroom

a. to the teacher's laptop,

b. for the students to download large files and videos.

3. To reduce exposure from Wi-Fi networks in school:

a. turn off Wi-Fi access points when not used for learning purposes,

b. position Wi-Fi access points outside of classrooms,

c. use directional Wi-Fi access points, which radiate into the direction of the client's device.

4. Keep laptops and tablets in flight mode when Internet is not needed for learning purposes.

5. Wired connection to a landline telephone in each classroom could minimize the need for mobile phones for contact.

6. Mobile phones, including smart phones, could be left at home or collected in turned off mode. If allowed, they should be carried only in flight mode during school hours.

the duty cycle can affect cell systems more in the human body. Since cancer tumors usually take several decades to develop and chronic illnesses, like cardiac and neurological diseases, come in older ages only the future will tell if and to what degree the RF radiation may have had an impact on these illnesses.

More worrying for today is the increase in behavioral problems in children like ADHD, the increasing sleep problems among children, and mental illnesses with anxiety, depressed mood, and suicide thoughts $(11,17-23,25,53-56)$. Children are probably more sensitive to RF radiation because of their growing bodies and more immature cells, but also because they will be exposed throughout their life-time $(41,44,45)$.

Given the abundance of microwaves in the modern environment, it is of importance that children grow up in an electromagnetic safe environment. The scientific research this far gives no guarantees for safety from the RF radiation. Children should be exposed to as low-RF radiation as possible both in school and at home. Wired connection for both the Internet and telephone communications should be preferred to minimize children's exposure to the wireless radiation, Table $\mathbf{1 0 .}$

\section{In Conclusion}

1. The ICNIRP guidelines are based on short-term heating (thermal) effects, and are therefore not relevant to decide on the appropriateness of long-term exposure.

2. The environmental exposure to RF radiation in some schools is higher than reported levels for non-thermal biological effects. In order to reduce children's exposure to RF radiation, schools should prefer wired network connections, allow laptop, tablets, and mobile phone usage only in flight mode and deactivate $\mathrm{Wi}-\mathrm{Fi}$ access points when internet is not needed for learning purposes.

\section{ETHICS STATEMENT}

This study was carried out in accordance with the recommendations of The Ethical Committee, Uppsala University, with written 
informed consent from all subjects: all subjects gave written informed consent in accordance with the Declaration of Helsinki. The protocol was approved by The Ethical Committee, Uppsala University, Sweden (DNR 2015/485).

\section{AUTHOR CONTRIBUTIONS}

$\mathrm{LKH}$ and $\mathrm{LH}$ made contributions to the conception and design of the study. LKH, LH, and TK handled the measurements and information to schools and teachers. TK contributed with technical advice for the exposimeters and the measurements. MC made the statistical analyses, the tables, and the figures. All the

\section{REFERENCES}

1. Spitzer M. Information technology in education: risks and side effects. Trends Neurosci Educ (2014) 3:81-5. doi:10.1016/j.tine.2014.09.002

2. OECD. Students, Computers and Learning: Making the Connection. Paris: PISA, OECD Publishing (2015).

3. OECD. PISA 2015, Results in Focus. OECD Publishing (2016). Available from: http://www.oecd-ilibrary.org/docserver/download/aa9237e6-en.pdf?expires $=1498048762 \& \mathrm{id}=\mathrm{id} \& \mathrm{xacname}=$ guest $\&$ checksum $=$ E0DA5D00420EFEAB0 B51B1F1286FE0F4

4. Ophir E, Nass C, Wagner AD. Cognitive control in media multitaskers. Proc Natl Acad Sci U S A (2009) 106:15583-7. doi:10.1073/pnas.0903620106

5. Kraushaar JM, Novak DC. Examining the affects of student multitasking with laptops during the lecture. J Info Syst Educ (2010) 21:241-51. Available from: http://jise.org/Volume21/21-2/Pdf/vol21-2-pg241.pdf

6. Minear M, Brasher F, McCurdy M, Lewis J, Younggren A. Working memory, fluid intelligence, and impulsiveness in heavy media multitaskers. Psychon Bull Rev (2013) 20:1274-81. doi:10.3758/s13423-013-0456-6

7. Hensinger P. Big data: a paradigm shift in education from personal autonomy to conditioning toward excessive consumerism. Umwelt Medizin Gesellschaft (2015) 28:206-13.

8. Sana F, Weston T, Cepeda NJ. Laptop multitasking hinders classroom learning for both users and nearby peers. Comput Educ (2013) 62:24-31. doi:10.1016/j. compedu.2012.10.003

9. Levitin DJ. The Organized Mind. Thinking Straight in the Age of Information Overload. New York: Dutton Books (2014). 528 p.

10. Rosendahl Å. Skolbarns hälsa och levnadsvanor 2015/2016. Tabeller. Luleå: Folkhälsocentrum, Norrbottens läns landsting (2017). Available from: http://www.norrbotten.se/publika/lg/utv/Folkh\%c3\%a4lsocentrum/ H\%c3\%a4lsosamtal/Barn/Rapporter/2015\%202016/Skolbarns\%20 h\%c3\%a4lsa\%20och\%20levnadsvanor\%2020152016_rapport.pdf

11. Roberts JA, Yaya LH, Manolis C. The invisible addiction: cell phone activities and addiction among male and female college students. J Behav Addict (2014) 3:254-65. doi:10.1556/JBA.3.2014.015

12. Maher C, Olds TS, Eisenmann JC, Dollman J. Screen time is more strongly associated than physical activity with overweight and obesity in 9- to 16-year old Australians. Acta Paediatr (2012) 101:1170-4. doi:10.1111/j.1651-2227.2012.02804.x

13. Ekblom-Bak E, Ekblom Ö, Bergström G, Börjesson M. Isotemporal substitution of sedentary time by physical activity of different intensities and bout lengths, and its associations with metabolic risk. Eur J Prev Cardiol (2016) 23:967-74. doi:10.1177/2047487315619734

14. Lepp A, Barkley JF, Sanders GJ, Rebold M, Gates P. The relationship between cell phone use, physical and sedentary activity, and cardiorespiratory fitness in a sample of U.S. college students. Int J Behav Nutr Phys Act (2013) 10:79. doi:10.1186/1479-5868-10-79

15. Lagercrantz $\mathrm{H}$. Too much time in front of the screen shatters children's lives. Obesity, concentration problems, impaired language development etc. may be the result. Läkartidningen (2013) 110:16-7. Available from: http://www. lakartidningen.se/OldWebArticlePdf/1/19078/LKT1301s16.pdf authors agreed on the risk management principles. LKH drafted the manuscript. All authors revised the manuscript and gave approval to the final version to be published.

\section{ACKNOWLEDGMENTS}

The authors want to thank the school principals and the participating teachers, who made this study possible. The study was supported by grants from Mr. Brian Stein, Cancer - och Allergifonden, and Cancerhjälpen. The funders had no role in study design, data collection, and analysis, decision to publish, or preparation of the manuscript.

16. Konrath SH, O'Brien EH, Hsing C. Changes in dispositional empathy in American college students over time: a meta-analysis. Pers Soc Psychol Rev (2011) 15:180-98. doi:10.1177/1088868310377395

17. Thomée S, Delive L, Härenstam A, Hagberg M. Perceived connections between information and communication technology use and mental symptoms among young adults-a qualitative study. BMC Public Health (2010) 10:66. doi:10.1186/1471-2458-10-66

18. Munezawa T, Kaneita Y, Osaki Y, Kanda H, Minowa M, Suzuki K, et al. The association between use of mobile phones after lights out and sleep disturbances among Japanese Adolescents: a nationwide cross-sectional survey. Sleep (2011) 34:1013-20. doi:10.5665/SLEEP.1152

19. Oshima N, Nishida A, Shimodera S, Tochigi M, Ando S, Yamasaki S, et al. The suicidal feelings, self-injury and mobile phone use after lights out in adolescents. JPediatr Psychol (2012) 37:1023-30. doi:10.1093/ jpepsy/jss072

20. Carter B, Rees P, Hale L, Bhattacharjee D, Paradkar MS. Association between portable screen-based media device access or use and sleep outcomes: a systematic review and meta-analysis. JAMA Pediatr (2016) 170:1202-8. doi:10.1001/jamapediatrics.2016.2341

21. Ikeda K, Nakamura K. Association between mobile phone use and depressed mood in Japanese adolescents: a cross-sectional study. Environ Health Prev Med (2014) 19:187-93. doi:10.1007/s12199-013-0373-3

22. Jun $\mathrm{S}$. The reciprocal longitudinal relationships between mobile phone addiction and depressive symptoms among Korean adolescents. Comput Hum Behav (2016) 58:179-86. doi:10.1016/j.chb.2015.12.061

23. George MJ, Russell M, Piontak J, Odgers C. Concurrent and subsequent associations between daily digital technology use and high-risk adolescents' mental health symptoms. Child Dev (2017). doi:10.1111/cdev.12819

24. Roser K, Schoeni A, Foerster M, Röösli M. Problematic mobile phone use of Swiss adolescents: is it linked with mental health or behaviour? Int J Public Health (2016) 61:307-15. doi:10.1007/s00038-015-0751-2

25. Folkhälsomyndigheten. Skolbarns hälsovanor i Sverige 2013/14. Grundrapport. Stockholm: Folkhälsomyndigheten (2014). Available from: https://www. folkhalsomyndigheten.se/contentassets/fbcbd76d2cae4fc0981e35dddf246cf0/ skolbarns-halsovanor-sverige-2013-14.pdf

26. ICNIRP. Guidelines for limiting exposure to time-varying electric, magnetic, and electromagnetic fields (up to $300 \mathrm{GHz}$ ). International commission on non-ionizing radiation protection. Health Phys (1998) 74:494-522.

27. Carpenter D. Human disease resulting from exposure to electromagnetic fields. Rev Environ Health (2013) 28:159-72. doi:10.1515/reveh-2013-0016

28. BioInitiative Working Group, Sage C, Carpenter DO, editors. BioInitiative Report: A Rationale for Biologically-Based Public Exposure Standards for Electromagnetic Radiation (2012). Available from: http://www.bioinitiative.org

29. Council of Europe. Résolution 1815. The Potential Dangers of Electromagnetic Fields and Their Effect on the Environment (2011). Available from: http://www. naturalscience.org/wp-content/uploads/2015/01/next-up-org_council-ofeurope_05-11_english.pdf

30. Baan R, Grosse Y, Lauby Secretan B, El Ghissassi F, Bouvard V, BenbrahimTallaa L, et al. Carcinogenicity of radiofrequency electromagnetic fields. Lancet Oncol (2011) 12:624-6. doi:10.1016/S1470-2045(11)70147-4 
31. IARC. IARC monographs on the evaluation of carcinogenic risks to humans. Non-Ionizing Radiation, Part 2: Radiofrequency Electromagnetic Fields (Vol. 102), Lyon, France: International Agency for Research on Cancer (2013). Available from: http://monographs.iarc.fr/ENG/Monographs/vol102/mono102.pdf

32. Hardell L, Carlberg M, Hansson Mild K. Pooled analysis of case-control studies on malignant brain tumours and the use of mobile and cordless phones including living and deceased subjects. Int J Oncol (2011) 38:1465-74. doi:10.3892/ijo.2011.947

33. Interphone Study Group. Brain tumour risk in relation to mobile telephone use: results of the INTERPHONE international case-control study. Int J Epidemiol (2010) 39:675-94. doi:10.1093/ije/dyq079

34. Hardell L, Carlberg M. Using the Hill viewpoints from 1965 for evaluating strengths of evidence of the risk for brain tumors associated with use of mobile and cordless phones. Rev Environ Health (2013) 28:97-106. doi:10.1515/reveh2013-0006

35. Coureau G, Bouvier G, Lebailly P, Fabbro-Peray P, Gruber A, Leffondre K, et al. Mobile phone use and brain tumours in the CERENAT, case-control study. Occup Environ Med (2014) 71:514-22. doi:10.1136/oemed-2013-101754

36. Hardell L, Carlberg M. Mobile phone and cordless phone use and the risk for glioma-analysis of pooled case-control studies in Sweden, 1997-2003 and 2007-2009. Pathophysiology (2015) 22:1-13. doi:10.1016/j.pathophys. 2014.10.001

37. Carlberg M, Hardell L. Evaluation of mobile phone and cordless phone use and glioma risk using the Bradford Hill viewpoints from 1965 on association or causation. Biomed Res Int (2017) 2017:9218486. doi:10.1155/2017/9218486

38. Wyde ME, Cesta MF, Blystone CR, Bucher JR, Elmore SA, Foster P, et al. Report of partial findings from the national toxicology program carcinogenesis studies of cell phone radiofrequency radiation in Hsd: Sprague Dawley ${ }^{\circledR}$ SD rats (whole body exposures). Draft 5-19-2016. US National Toxicology Program (NTP) (2016). doi:10.1101/055699

39. Akdag MZ, Dasdag S, Canturk F, Karabulut D, Caner Y, Adalier N. Does prolonged radiofrequency radiation emitted from Wi-Fi devices induce DNA damage in various tissues of rats? JChem Neuroanat (2016) 75:116-22. doi:10.1016/j.jchemneu.2016.01.003

40. Dasdag S, Akdag MZ, Erdal ME, Erdal N, Ay OI, Ay ME, et al. Effects of 2.4 $\mathrm{GHz}$ radiofrequency radiation emitted from Wi-Fi equipment on microRNA expression in brain tissue. Int J Radiat Biol (2015) 91:555-61. doi:10.3109/09 553002.2015.1028599

41. Markova E, Malmgren LOG, Belyaev IY. Microwaves from mobile phones inhibit 53BP1 focus formation in human stem cells more strongly than in differentiated cells: possible mechanistic link to cancer risk. Environ Health Perspect (2010) 118:394-9. doi:10.1289/ehp.0900781

42. Megha K, Deshmukh PS, Banerjee BD, Tripathi AK, Ahmed R, Abegaonkar MP. Low intensity microwave radiation induced oxidative stress, inflammatory response and DNA damage in rat brain. Neurotoxicology (2015) 51:158-65. doi:10.1016/j.neuro.2015.10.009

43. Yakymenko I, Tsybulin O, Sidorik E, Henshel D, Kyrylenko O, Kyrylenko S. Oxidative mechanisms of biological activity of low-intensity radiofrequency radiation. Electromagn Biol Med (2016) 35:186-202. doi:10.3109/15368378. 2015.1043557

44. Morgan LL, Kesari S, Davis DL. Why children absorb more microwave radiation than adults: the consequences. J Microsc Ultrastruct (2014) 2:197-204. doi:10.1016/j.jmau.2014.06.005

45. Gerner C, Haudek V, Schandl U, Bayer E, Gundacker N, Hutter HP, et al. Increased protein synthesis by cells exposed to a $1,800-\mathrm{MHz}$ radio-frequency mobile phone electromagnetic field, detected by proteome profiling. Int Arch Occup Environ Health (2010) 83:691-702. doi:10.1007/s00420-010-0513-7

46. Salford LG, Brun AE, Eberhardt JL, Malmgren L, Persson BR. Nerve cell damage in mammalian brain after exposure to microwaves from GSM mobile phones. Environ Health Perspect (2003) 111:881-3. doi:10.1289/ehp.6039

47. Nittby H, Grafström G, Tian DP, Malmgren L, Brun A, Persson BR, et al. Cognitive impairment in rats after long-term exposure to GSM-900 mobile phone radiation. Bioelectromagnetics (2008) 29:219-32. doi:10.1002/ bem. 20386

48. Tang J, Zhang Y, Yang L, Chen Q, Tan L, Zuo S, et al. Exposure to $900 \mathrm{MHz}$ electromagnetic fields activates the mkp-1/ERK pathway and causes bloodbrain barrier damage and cognitive impairment in rats. Brain Res (2015) 1601:92-101. doi:10.1016/j.brainres.2015.01.019
49. Sirav B, Seyhan N. Effects of GSM modulated radio-frequency electromagnetic radiation on permeability of blood-brain barrier in male \& female rats. JChem Neuroanat (2016) 75:123-7. doi:10.1016/j.jchemneu.2015. 12.010

50. Fragopoulou AF, Samara A, Antonelou MH, Xanthopoulou A, Papadopoulou A, Vougas K, et al. Brain proteome response following whole body exposure of mice to mobile phone or wireless DECT base radiation. Electromagn Biol Med (2012) 31:250-74. doi:10.3109/15368378.2011.631068

51. Megha K, Deshmukh PS, Ravi AK, Tripathi AK, Abegaonkar MP, Banerjee BD. Effect of low-intensity microwave radiation on monoamine neurotransmitters and their key regulating enzymes in rat brain. Cell Biochem Biophys (2015) 73:93-100. doi:10.1007/s12013-015-0576-x

52. Buchner K, Eger $\mathrm{H}$. Changes of clinically important neurotransmitters under the influence of modulated RF-fields-a long term study under real-life conditions. Umwelt Medizin Gesellschaft (2011) 24:44-57.

53. Thomas S, Heinrich S, von Kries R, Radon K. Exposure to radio-frequency electromagnetic fields and behavioural problems in Bavarian children and adolescents. Eur J Epidemiol (2010) 25:135-41. doi:10.1007/ s10654-009-9408-x

54. Divan HA, Kheifets L, Obel C, Olsen J. Cell phone use and behavioural problems in young children. J Epidemiol Community Health (2012) 66:524-9. doi:10.1136/jech.2010.115402

55. Calvente I, Pérez-Lobato R, Núñez MI, Ramos R, Guxens M, Villalba J, et al. Does exposure to environmental electromagnetic fields cause cognitive and behavioral effects in 10-year-old boys? Bioelectromagnetics (2016) 37:25-36. doi:10.1002/bem.21951

56. Sudan M, Olsen J, Arah OA, Obel C, Kheifets L. Prospective cohort analysis of cellphone use and emotional and behavioural difficulties in children. JEpidemiol Community Health (2016) 70:1207-13. doi:10.1136/ jech-2016-207419

57. Lowden A, Akerstedt T, Ingre M, Wiholm C, Hillert L, Kuster N, et al. Sleep after mobile phone exposure in subjects with mobile phone-related symptoms. Bioelectromagnetics (2011) 32:4-14. doi:10.1002/bem.20609

58. Krause CM, Björnberg CH, Pesonen M, Hulten A, Liesivuori T, Koivisto M, et al. Mobile phone effects on children's event-related oscillatory EEG during an auditory memory task. Int J Radiat Biol (2006) 82:443-50. doi:10.1080/ 09553000600840922

59. Volkow ND, Tomasi D, Wang GJ, Vaska P, Fowler JS, Telang F, et al. Effects of cell phone radiofrequency signal exposure on brain glucose metabolism. JAMA (2011) 305:808-13. doi:10.1001/jama.2011.186

60. Sangün Ö, Dündar B, Çömlekçi S, Büyükgebiz A. The effects of electromagnetic field on the endocrine system in children and adolescents. Pediatr Endocrinol Rev (2015) 13:531-45.

61. Söderqvist F, Carlberg M, Zetterberg H, Hardell L. Use of wireless phones and serum $\beta$-trace protein in randomly recruited persons aged 18-65 years: a cross-sectional study. Electromagn Biol Med (2012) 31:416-24. doi:10.3109/ 15368378.2012.683224

62. Çam ST, Seyhan N. Single-strand DNA breaks in human hair root cells exposed to mobile phone radiation. Int J Radiat Biol (2012) 88:420-4. doi:10.3109/ 09553002.2012.666005

63. Banjeree S, Singh NN, Sreedhar G, Mukherjee S. Analysis of the genotoxic effects of mobile phone radiation using buccal micronucleus assay: a comparative evaluation. J Clin Diagn Res (2016) 10:ZC82-5. doi:10.7860/ JCDR/2016/17592.7505

64. Avendaño C, Mata A, Sanchez Samiento CA, Doncel GF. Use of laptop computer connected to internet through Wi-Fi decreases human sperm motility and increases sperm fragmentation. Fertil Steril (2012) 97:39-45. doi:10.1016/j.fertnstert.2011.10.012

65. Atasoy HI, Gunal MY, Atasoy P, Elgun S, Bugdayci G. Immunohistopathologic demonstration of deleterious effects on growing rat testes of radiofrequency waves emitted from conventional Wi-Fi devices. J Pediatr Urol (2013) 9:223-9. doi:10.1016/j.jpurol.2012.02.015

66. Dasdag S, Tas M, Akdag MZ, Yegin K. Effect of long-term exposure of 2.4 $\mathrm{GHz}$ radiofrequency radiation emitted from Wi-Fi equipment on testes functions. Electromagn Biol Med (2015) 34:37-42. doi:10.3109/15368378.2013. 869752

67. Saili L, Hanini A, Smirani C, Azzouz I, Azzouz A, Sakly M, et al. Effects of acute exposure to WiFi signals $(2.45 \mathrm{GHz})$ on heart variability and blood pressure 
in Albinos rabbit. Environ Toxicol Pharmacol (2015) 40:600-5. doi:10.1016/j. etap.2015.08.015

68. Tök L, Naziroglu M, Dogan S, Kahya MC, Tök Ö. Effects of melatonin on WiFi-induced oxidative stress in lens of rats. Indian JOphthalmol (2014) 62:12-5. doi:10.4103/0301-4738.126166

69. Deshmukh PS, Nasare N, Megha K, Banerjee BD, Ahmed RS, Singh D, et al. Cognitive impairment and neurogenotoxic effects in rats exposed to low-intensity microwave radiation. Int J Toxicol (2015) 34:284-90. doi:10.1177/1091581815574348

70. Papageorgiou C, Hountala C, Maganioti A, Kyprianou M, Rabavilas A, Papadimitriou G, et al. Effects of Wi-Fi signals on the P300 component of event-related potentials during an auditory hayling task. J Integr Neurosci (2011) 10:189-202. doi:10.1142/S0219635211002695

71. Zentai N, Csathó Á, Trunk A, Fiocchi S, Parazzini M, Ravazzini P, et al. No effects of acute exposure to Wi-Fi electromagnetic fields on spontaneous EEG activity and psychomotor vigilance in healthy human volunteers. Radiat Res (2015) 184:568-77. doi:10.1667/RR13896.1

72. Estenberg J, Augustsson T. Extensive frequency selective measurements of radiofrequency fields in outdoor environments performed with a novel mobile monitoring system. Bioelectromagnetics (2014) 35:227-30. doi:10.1002/ bem. 21830

73. Hardell L, Koppel T, Carlberg M, Ahonen M, Hedendahl L. Radiofrequency radiation at Stockholm Central Railway Station in Sweden and some medical aspects on public exposure to RF fields. Int J Oncol (2016) 49:1315-24. doi:10.3892/ijo.2016.3657

74. Hardell L, Carlberg M, Koppel T, Hedendahl L. High radiofrequency radiation at Stockholm Old Town: an exposimeter study including the Royal Castle, Supreme Court, three major squares and the Swedish Parliament. Mol Clin Oncol (2017) 6:462-76. doi:10.3892/mco.2017.1180

75. Peyman A, Khalid M, Calderon C, Addison D, Mee T, Maslanyj M, et al. Assessment of exposure to electromagnetic fields from wireless computer networks (Wi-Fi) in schools; results of laboratory measurements. Health Phys (2011) 100:594-612. doi:10.1097/HP.0b013e318200e203

76. Vermeeren G, Markakis I, Goeminne F, Samaras T, Martens L, Joseph W. Spatial and temporal RF electromagnetic field exposure of children and adults in indoor micro environments in Belgium and Greece. Prog Biophys Mol Biol (2013) 113:254-63. doi:10.1016/j.pbiomolbio.2013.07.002

77. Valic B, Kos B, Gajsek P. Typical exposure of children to EMF: exposimetry and dosimetry. Radiat Prot Dosimetry (2015) 163:70-80. doi:10.1093/rpd/ ncu057

78. Verloock L, Wout J, Goeminne F, Martens L, Verlaek M, Constandt K. Assessment of radiofrequency exposures in schools, homes, and public places in Belgium. Health Phys (2014) 107:503-13. doi:10.1097/ HP. 0000000000000149

79. Roser K, Schoeni A, Struchen B, Zahner M, Eeftens M, Fröhlich J, et al. Personal radiofrequency electromagnetic field exposure measurements in Swiss adolescents. Environ Int (2017) 99:303-14. doi:10.1016/j.envint.2016.12.008

80. Gajšek P, Struchen B, Valič B. RF exposure survey of children and adults: first results from Slovenia. IEEE Radio and Antenna Days of the Indian Ocean (RADIO) (2016). Available from: http://ieeexplore.ieee.org/document/ $7772027 /$

81. Kurnaz Ç, Engiz BK, Bozkurt MC. Monitoring of RF/microwave field strength at schools in a pilot district in Samsun/Turkey. Microwave Symposium (MMS) 16th Mediterranean, Abu Dhabi (2016).
82. Bhatt CR, Redmayne M, Billah B, Abramson MJ, Benke G. Radiofrequencyelectromagnetic field exposures in kindergarten children. J Exp Sci Environ Epidemiol (2016) 27(5):497-504. doi:10.1038/jes.2016.55

83. Karipidis K, Henderson S, Wijayasinghe D, Tjong L, Tinker R. Exposure to radiofrequency electromagnetic fields from Wi-Fi in Australian schools. Radiat Prot Dosimetry (2017) 175(4):432-9. doi:10.1093/rpd/ncw370

84. Khalid M, Mee T, Peyman A, Addison D, Calderon C, Maslanyj M, et al. Exposure to radio frequency electromagnetic fields from wireless computer networks: duty factors of Wi-Fi devices operating in schools. Prog Biophys Mol Biol (2011) 107:412-20. doi:10.1016/j.pbiomolbio.2011.08.004

85. Joseph W, Pareit D, Vermereen G, Naudts D, Verlock L, Martens L, et al. Determination of the duty cycle of WLAN for realistic radio frequency electromagnetic field exposure assessment. Prog Biophys Mol Biol (2013) 111:30-6. doi:10.1016/j.pbiomolbio.2012.10.002

86. Foster KR, Moulder JE. Wi-Fi and health: review of current status of research. Health Phys (2013) 105:561-75. doi:10.1097/HP.0b013e31829b49bb

87. Koppel T, Ahonen M. Radiofrequency electromagnetic fields from mobile devices used for learning and working. Electron Electr Eng (2013) 6:65-70. doi:10.5755/j01.eee.19.6.4565

88. Koppel T, Tasa T, Tint P. Electromagnetic fields in contemporary office workplaces. Agron Res (2013) 11:421-34.

89. Bolte JF, Maslanyj M, Addison D, Mee T, Kamer J, Colussi L. Do car-mounted mobile measurements used for radio-frequency spectrum regulation have an application for exposure assessments in epidemiological studies? Environ Int (2016) 86:75-83. doi:10.1016/j.envint.2015.09.024

90. Gryz K, Zradzinski P, Karpowicz J. The role of the location of personal exposimeters on the human body in their use for assessing exposure to the electromagnetic field in the radiofrequency range $98-2450 \mathrm{MHz}$ and the compliance analysis: evaluation by virtual measurements. Biomed Res Int (2015) 2015:272460. doi:10.1155/2015/272460

91. Bhatt CR, Thielens A, Redmayne M, Abramson MJ, Billah B, Sim MR, et al. Measuring personal exposure from $900 \mathrm{MHz}$ mobile phone base stations in Australia and Belgium using a novel personal distributed exposimeter. Environ Int (2016) 9(2-93):388-97. doi:10.1016/j.envint.2016.03.032

92. Hedendahl L, Carlberg M, Hardell L. Electromagnetic hypersensitivity-an increasing challenge to the medical profession. Rev Environ Health (2015) 30:209-15. doi:10.1515/reveh-2015-0012

93. Nittby H, Brun A, Eberhardt J, Malmgren L, Persson BR, Salford LG. Increased blood-brain barrier permeability in mammalian brain 7 days after exposure to the radiation from a GSM-900 mobile phone. Pathophysiology (2009) 16:103-12. doi:10.1016/j.pathophys.2009.01.001

Conflict of Interest Statement: The authors declare that the research was conducted in the absence of any commercial or financial relationships that could be construed as a potential conflict of interest.

The reviewer HM and handling editor declared their shared affiliation.

Copyright $\odot 2017$ Hedendahl, Carlberg, Koppel and Hardell. This is an open-access article distributed under the terms of the Creative Commons Attribution License (CC BY). The use, distribution or reproduction in other forums is permitted, provided the original author $(s)$ or licensor are credited and that the original publication in this journal is cited, in accordance with accepted academic practice. No use, distribution or reproduction is permitted which does not comply with these terms. 